\title{
Francesco Grimaldi, un mercader-banquero genovés entre Granada, la Corte e Inglaterra (siglos XV-XVI) ${ }^{1}$
}

\section{Francesco Grimaldi, a Genoese Merchant-Banker Active in Granada, the Court and England $\left(15^{\text {th }}-16^{\text {th }}\right.$ Centuries $)$}

\author{
Raúl GonzÁlez ArÉvalo \\ Universidad de Granada \\ rgonzalezarevalo@ugr.es
}

Recibido: 06/09/2015

Aceptado: 18/11/2015

\begin{abstract}
RESUMEN
Los estudios sobre la comunidad genovesa del Reino de Granada suelen centrarse en las actividades desarrolladas en el territorio y rara vez en la reconstrucción de trayectorias individuales, circunstancia determinada por el recurso casi exclusivo a los protocolos notariales. El caso de Francesco Grimaldi es singular por muchas razones: su localización en fuentes de naturaleza muy variada -protocolos notariales de Granada y Málaga, Registro del Sello de Simancas y Granada, Chancillería de Valladolid, el epistolario del comendador Fuensalida y el archivo privado de la familia Grimaldo de Cáceres- ha permitido seguir su presencia y sus actividades en Granada, la Corte e Inglaterra -donde desempeñó un papel fundamental en el matrimonio entre Catalina de Aragón y Enrique VIII-. Así se conoce su interés por los préstamos y el negocio de la renta, las circunstancias de su matrimonio con Francisca de Cáceres y la adquisición de un importante patrimonio en el reino granadino.
\end{abstract}

Palabras clave: genoveses, extranjeros, Granada, Corte, Inglaterra, Gómez de Fuensalida, Catalina de Aragón.

\begin{abstract}
Studies on the Genoese community in the Kingdom of Granada have mainly focused on activities carried out in the territory, and only rarely have individual biographies been reconstructed, largely due to the almost exclusive use of notarial deeds. The case of Francesco Grimaldi is unique for several reasons. $\mathrm{He}$ is mentioned in very different sources, including notarial deeds from Granada and Málaga, the Seal Register of Simancas and Granada, the Chancellery of Valladolid, the collected letters of the ambassador Fuensalida, and the private archive of the Grimaldo de Cáceres family, and this has made it possible to trace his presence and activities in Granada, the Court and England -where he played a key role in the marriage between Katherine of Aragon and Henry VIII. It has also been possible to elucidate his busi-
\end{abstract}

${ }^{1}$ El presente artículo forma parte del proyecto "Presencia diferencial italiana en el sur de la Península Ibérica en época Trastámara (siglos XIV-XVI)" (RYC-2011-09300), financiado por el programa Ramón y Cajal del Ministerio de Economía y Competitividad, desarrollado en la Universidad de Granada. 
ness activities related to loans and rents, the circumstances of his marriage to Francisca de Caceres and his acquisition of an important estate in the Kingdom of Granada.

Key Words: Genoese, Foreigners, Granada, Court, England, Gómez de Fuensalida, Katherine of Aragon.

Sumario: 1. Primeros años en Granada (c. 1496-1503): el interés por el negocio de la renta y los préstamos. 2. La estancia en la Corte (1503-1508). 3. Inglaterra (1508-1510): la dote de Catalina de Aragón. 4. Inglaterra (1508): el matrimonio con Francisca de Cáceres. 5. Última estancia en Granada (15101519/20): el patrimonio de Francesco Grimaldi. 6. La familia Grimaldo de Cáceres (Granada, primera mitad del siglo XVI). 7. Consideraciones finales. 8. Bibliografía.

Si hay un colectivo caracterizado por su movilidad en la Edad Media tardía ése es, sin duda, el de los mercaderes. Ya fueran grandes o pequeños, ya fuera de corto o de largo alcance el radio de sus operaciones, lo cierto es que los comerciantes medievales, cristianos, musulmanes y judíos, se desplazaron a lo largo y ancho de Europa y el Mediterráneo, sirviendo de enlace entre regiones.

Por otra parte, la importancia del comercio en el desarrollo económico de la Península Italiana hizo que algunos territorios dieran prioridad a las actividades comerciales, de modo que el grupo de los mercaderes tuvo un peso importante en la sociedad $\mathrm{y}$, a la postre también en la política de las llamadas repúblicas mercantiles, con tres nombres a la cabeza en el siglo XV: Génova, Venecia y Florencia. Y en la proyección económica y comercial de esas tres ciudades-Estado emblemáticas la Península Ibérica desempeñó un papel fundamental, como ha revelado una tradición historiográfica consolidada ${ }^{2}$.

Como es ampliamente sabido, en el Reino de Granada el grupo mercantil más destacado, en época nazarí como castellana, fue el de los genoveses. El empleo del método prosopográfico ha permitido profundizar en la trayectoria vital y profesional de sus miembros más destacados. Así, en época musulmana destacaron particularmente los Spinola ${ }^{3}$, mientras que para el período castellano son bien conocidas las condiciones del arraigo de los Centurión y los Italián en Málaga ${ }^{4}$. Además, recientemente he tenido ocasión de reconstruir la trayectoria de Ambrogio Spinola, su hermano Luciano y sus sobrinos Manuel y Giovanni Battista entre el final de los tiempos nazaríes y los primeros años tras la conquista castellana ${ }^{5}$. Todos ellos se integraban en una importante red de contactos que se desarrollaba a distintos niveles, asimismo interconectados: la familia, la nación, los intereses comerciales y económicos ${ }^{6}$.

\footnotetext{
${ }^{2}$ Sin ánimo de ser exhaustivo, para la Corona de Aragón me remito al trabajo clásico de FerRer i MALLOL, "Els Italians"; asimismo resultan indispensables las obras más recientes de IGUAL LuIs, Valencia e Italia; y SoldANI, Uomini d'affari. La producción referente a la Corona de Castilla y el Reino de Granada en su etapa musulmana y cristiana la abordé en González ArÉvalo, "Presencia diferencial". Sobre los italianos en Portugal hay una vasta bibliografía recogida en D'ARIEnzo, La presenza.

3 Petti Balbi, "Le strategie"; Fábregas García, Un mercader genovés; idem, La familia Spinola.

${ }^{4}$ LÓPEZ de Coca y LóPez Beltrán, "Mercaderes genoveses".

5 González ArÉvalo, "Exilio"; idem, "De las postrimerías".

${ }^{6}$ En este sentido resultan ilustrativos trabajos como los de José Enrique López de Coca o Ildefonso Pulido sobre los Italian y los Centurión: LóPEz DE COCA, "Genoveses en la corte"; Pulido Bueno, La familia 
En esta ocasión me voy a centrar en otra figura singular cuyo estudio todavía no se había abordado. Se trata de Francesco Grimaldi, un mercader-banquero genovés cuyo perfil sobresale entre sus compatriotas establecidos en el reino granadino por la capacidad para adquirir un extenso patrimonio inmobiliario a partir del cual creará un mayorazgo, fruto de su inusual unión con una noble castellana, dama de honor de Catalina de Aragón cuando era princesa viuda de Gales. Precisamente el cruce de informaciones procedentes de actas notariales granadinas, del Archivo General de Simancas y de las Reales Chancillerías de Granada y de Valladolid permiten seguir la pista de sus actividades y la de su familia desde la Península Ibérica hasta Inglaterra y vuelta entre finales del siglo XV y los primeros tres lustros del siglo XVI, si bien los datos sobre su mujer y sus hijos se adentran hasta mediados del Quinientos, revelando un proceso particular de integración en la oligarquía granadina.

\section{PRIMEROS AÑOS EN GRANADA (C. 1496-1503): EL INTERÉS POR EL NEGOCIO DE LA RENTA Y LOS PRÉSTAMOS}

Resulta complicado situar los orígenes de la figura de Francesco Grimaldi. A diferencia de las familias Spinola y Centurione, que cuentan con múltiples estudios específicos, se sabe mucho menos sobre los Grimaldi hispanos ${ }^{7}$. Más aún, hasta el momento no se ha podido establecer conexión alguna con otros dos importantes genoveses localizados en la corte, Ansaldo y Juan Francisco de Grimaldo ${ }^{8}$. Además, no hay que confundirlo con este último, asociado con Gaspar Centurión, con quien funda un banco en Sevilla a principios del Quinientos?.

Las primeras noticias localizadas sobre Francesco Grimaldi lo sitúan directamente como mercader genovés vecino de Granada en 1496. Se ignora cuánto tiempo llevaba en el territorio y en qué momento se había avecindado en la ciudad. Ninguna referencia permite aventurar de forma aproximada todo este proceso. Sin embargo, dado su parentesco con Agustín Italián, no se puede descartar que llegara al reino granadino atraído por las oportunidades de negocio que estaba desarrollando su primo, ya establecido en Málaga en $1493^{10}$.

genovesa Centurión. La bibliografía sobre la organización de los italianos en Castilla es muy extensa. Para no extenderme en el tema me remito a mis trabajos citados en las notas 2 y 5 . Además, para principios del siglo XVI resulta muy acertado Alonso GARCía, "Una nación". Se trata de un modo de organización con la familia como unidad básica para el desarrollo de los intereses económicos, aplicable a otros territorios en el mismo período, como por ejemplo la Inglaterra Tudor: BRATCHEL, "Italian Merchant Organization".

7 Apenas he localizado un estudio, centrado en la figura de Jerónimo Grimaldi, activo entre Sevilla y La Española en 1489-1517: GARRIDO RAYA y MORENO EsCALANTE, "La red mercantil".

${ }^{8}$ Alonso García, "Genoveses en la Corte”. También proporciona datos sobre los Italian y los Centurion.

${ }^{9}$ La confusión en Pulido Bueno, La familia genovesa Centurión, pp. 72 y 74.

${ }^{10}$ El parentesco lo revela el comendador Gutierre Gómez de Fuensalida en una carta a Fernando el Católico desde Inglaterra en abril de 1508: "Ya escrivy a vuestra alteza quánto Françisco Grimaldo, prymo de Agvstín Italyán, que vino comigo, desea seruir a vuestra alteza". Duque De Berwick y DE Alba (ed.), Correspondencia, p. 444, 27-IV-1508. Sobre las actividades de Agustín Italián en Málaga en la última década del siglo XV, actuando en solitario o en compañía de Martín Centurión, cf. LóPEZ DE CocA y LóPEz Beltrán, "Mercaderes genoveses", pp. 109-114. 
En mayo de 1496 Francesco Grimaldi había tratado un pleito contra Pedro de la Plata ante el corregidor de Granada, siendo condenado este último a pagarle 71.834 maravedíes. Desafortunadamente no se especifica el origen del litigio, ni ha subsistido entre las causas conservadas en la Chancillería de Granada, donde se revisó, pero sí sabemos que Pedro de la Plata se negó a pagar y decidió apelar ${ }^{11}$. Dos meses más tarde descubrimos que la causa del juicio reside en unas casas que de la Plata había vendido a Grimaldi, pero se ignora tanto el motivo del desencuentro como el desenlace ${ }^{12}$.

Lo que sí parece claro es que entre los intereses primordiales de las actividades desarrolladas por Francesco Grimaldi se encontraban los préstamos. Así por ejemplo, en junio de 1497 había prestado junto con Juan de Gra 15.000 maravedíes a Lope de Baeza, que había arrendado la renta de las mancebías del Reino de Granada a los Núñez de Toledo ${ }^{13}$. En este punto surge un nuevo interrogante sobre la naturaleza y el origen de la relación de nuestro genovés con los Núñez de Toledo. Efectivamente, esta poderosa familia, residente en Granada, en 1495 ya había recibido la merced de las mancebías del reino y la detentó hasta finales de 1514. Fernán Núñez de Toledo y su hermano Antón -hijos de Francisco Núñez de Toledo, regidor de Madrid, hermano a su vez del tesorero real Ruy López de Toledo- gestionaban como propias las mancebías de las ciudades de Málaga, Vélez-Málaga y Almería.

Sin embargo, desde 1505 hasta septiembre de 1510 la mancebía de Málaga la arrendó Francisco Romero, vecino de Jaén, que la había comprado a su vez a Juan de Magaña, vecino de Vélez-Málaga y alcaide de Torre del Mar, por 35.000 maravedíes horros de alcabala, la misma cantidad por la que Magaña la había adquirido a Fernán Núñez de Toledo. Magaña había vendido el censo a Romero con la intención de recuperar el préstamo que le adeudaban los Núñez de Toledo por la misma cantidad, pero al parecer había realizado la operación sin ajustarse a la ley, en primer lugar porque éstos no habían aprobado la operación.

Ignoro en qué momento Francesco Grimaldi y Fernán Núñez de Toledo entraron en contacto, pero a principios de septiembre de 1510 este último reconocía que había sido condenado a pagar a nuestro genovés 70.000 maravedíes por una sentencia dada por el bachiller Hernán Gil Mogollón, alcalde de la Chancillería de Granada. En un primer momento recurrió la sentencia, pero posteriormente decidió renunciar a la apelación y se comprometió a pagar la cantidad sin pleito alguno ese mismo mes "porque vos agora me tenéys preso en la cárçel real de la Chançillería". Como garantía hipotecaba precisamente los derechos sobre las mancebías de Málaga, que eran suyas por una fianza que le había hecho a Juan de Soria, arrendador de las alcabalas de las ciudades de Guadix, Loja y Alfácar en años anteriores, y que se habían rematado en Francisco Romero. Dos semanas más tarde, el 25 de septiembre, Francesco Grimaldi anulaba ante el mismo notario la obligación dada por Núñez de Toledo

${ }^{11}$ Archivo de la Real Chancillería de Granada (en adelante ARChG), Registro del Sello (RS), 5501, 37, 26-V-1496.

${ }^{12}$ ARChG, RS, 5501, 38, 6-VII-1496.

${ }^{13}$ López Beltrán, La prostitución, p. 50, nota 100. La autora transcribe Juan de Guía, en contraposición a los protocolos granadinos. Se trata de la primera mención a Juan de Gra, pero no hay indicación de si ya entonces era cuñado de Grimaldi. 
porque le tomó en cuenta los 70.000 maravedíes mencionados de 300.000, porque le vendió 36.000 maravedíes de censo sobre las mancebías y casas de Málaga ${ }^{14}$. Al día siguiente Grimaldi permitía que Fernán Núñez cambiara el censo de 36.000 maravedíes sobre las mancebías, boticas y unas casas cerca de la Puerta de Antequera en Málaga que le había vendido por 300.000 maravedíes y lo impusiera sobre otras posesiones que tuviera en la ciudad, a condición de que tuvieran el mismo valor y en un plazo máximo de dos años y medio a partir de la fecha de la carta. Si no lo hiciera como se había acordado, las mancebías, las boticas y las casas quedarían cargadas con el censo ${ }^{15}$.

Con toda probabilidad Núñez de Toledo había podido anular la obligación contraída porque a partir del 20 de septiembre de 1510 había recuperado el control sobre las mancebías de Málaga gracias a una sentencia de la Chancillería granadina que obligaba a Francisco Romero a devolvérselas. Además, todo parece indicar que habría logrado sustituir en tiempo y forma el censo sobre las mancebías, pues los protocolos malagueños no conservan información en referencia a Francesco Grimaldi en este sentido. Por otra parte, es dudoso que nuestro genovés estuviera realmente interesado en una renta poco saneada ${ }^{16}$.

Las rentas de las mancebías de Málaga y los préstamos a los Núñez de Toledo no fueron las únicas actividades financieras desarrolladas por Francesco Grimaldi en los años en torno al cambio de siglo. Ni la única ocasión en la que recurrió a la justicia. Efectivamente, en septiembre de 1500 los monarcas habían ordenado a los contadores mayores que devolvieran a los arrendadores de la Alpujarra de los años 1494 a 1497 la cantidad de 1.060 .000 maravedíes por rentas que no podían cobrar en ese partido ${ }^{17}$. Dos meses más tarde la Corona despachaba una orden para que los mismos contadores mayores libraran a Grimaldi 70.000 maravedíes por las costas del pleito que le enfrentó con los moros de las Alpujarras por las rentas que debían a la Hacienda Real entre 1495 y $1498^{18}$.

La participación de Francesco Grimaldi en el arrendamiento de las rentas de la Alpujarra queda confirmada por una sentencia dada por dos jueces árbitros, los bachilleres de Santarén y de la Torre, en la concordia a la que llegaron de una parte García

14 DE la Obra Sierra, Mercaderes italianos, doc. 48.

15 Ibidem, doc. 52. El 31 de agosto de 1510 Grimaldi había apoderado a Francisco Fernández de Sosa, vecino de Villarrubia, en el Campo de Calatrava para que le representara en todos sus pleitos y negocios. Menos de un mes más tarde, el 25 de septiembre, coincidiendo con el acuerdo alcanzado con Núñez de Toledo, Grimaldi apoderaba a Francisco Marco, vecino de Granada. Ibidem, docs. 46 y 51 respectivamente.

${ }^{16}$ López Beltrán, La prostitución, pp. 48-55. El asunto de los derechos sobre las mancebías de Málaga aún colearía. En febrero de 1512 Juan de Gra, mercader genovés estante en Granada, sustituía el poder que tenía de su cuñado Grimaldi en Bartolomé de la Roca y en Batin Peyran, mercaderes genoveses estantes en Málaga, para que notificaran a Fernán Núñez de Toledo cierto escrito de requerimiento y demanda que doña Francisca de Fajardo le puso a Grimaldi ante el presidente y oidores de la Chancillería de Granada; y para que se opusieran a cualquier ejecución sobre las mancebías de Málaga, sobre las que Grimaldi había comprado 36.000 maravedíes de censo a Fernán Núñez de Toledo. De la Obra SiERra, Mercaderes italianos, doc. 100, $10-\mathrm{II}-1512$.

17 AGS, Libros de Cédulas, 4, fols. $158 \mathrm{v}^{\circ}-159$, 14-IX-1500. He consultado el documento en TriLlO SAN José, La Alpujarra, Apéndice documental, doc. 40.

18 AGS, Cámara de Castilla (en adelante CC), Cédulas, 4, 213, 8, 2-XI-1500. Salvo indicación contraria, los documentos procedentes del Archivo General de Simancas se han consultado en PARES, Portal de Archivos Españoles [http://pares.mcu.es/]. 
de Alcocer, Fernand Francés y el genovés Francisco de Marin, vecinos de Granada, y de otra Francisco de Peñalver y Francesco Grimaldi a propósito del desacuerdo sobre 600.000 maravedíes que los Reyes Católicos libraron en descuento de la dicha renta de los años 1496 y 1497. Alcocer, Francés y Marín temían que al recibir el libramiento Peñalver y Grimaldi éstos no realizaran la partición ordenada por los jueces, por lo que solicitaron a los monarcas que decretaran el cumplimiento del arbitraje ${ }^{19}$. Parece bastante probable que Peñalver y Grimaldi tuvieran una compañía financiera para cobrar la citada renta, al estilo de otras compañías integradas por extranjeros y nacionales ${ }^{20}$.

No sería la última ocasión en que Francesco Grimaldi recurriría a la justicia. En octubre de 1502 era él quien apelaba a los soberanos por problemas en la ciudad de Jaén, cuya naturaleza se ignora. Efectivamente, en fecha desconocida había tomado como letrado al bachiller Juan de Santoyo, antiguo alcalde de la ciudad, a quien entregó una cantidad indeterminada como adelanto. Grimaldi permaneció en la ciudad hasta que la demanda estuvo terminada y entregada al procurador, y se marchó confiado en la buena marcha del proceso. Sin embargo, por razones aún oscuras el bachiller Santoyo "se conçertó con las partes contrarias e tomó la demanda al procurador e no le consyntió que la presentase". La traición de su letrado obligó al genovés a buscar otro nuevo para seguir adelante con el proceso. Pero no sólo, Grimaldi se desplazó hasta Jaén para exigir explicaciones a Santoyo y procurar que fuera detenido. Sin embargo, se encontró con la pasividad de las autoridades locales, que encubrieron al antiguo alcalde ${ }^{21}$ :

Francisco Grimaldo vino a la dicha cibdad de Jahé(n) e dixo al dicho bachiller que por qué él auía fecho tan mala obra, porque quando pensó que su pleito estaría fenescido no estava començado, e desto el dicho bachiller dis que ovo mucho enojo y delante de muchas personas alçó vna mano e le dio vna bofetada estando en el cementerio de la yglesia maior de la dicha cibdad, e dis que el bachiller Calderón, alcalde en la dicha cibdad, diz que lo pudiera prender e lo disimuló a cabsa de la mucha amistad que con él tiene, e que otra vez le pudiera prender pasándose de vna yglesia a otra menos lo quiso faser, e que él no podía alcançar del dicho bachiller Juan de Santoyo conplimiento de justicia en la dicha cibdad por ser oidores enparentados e fauorescido en ella, e nos suplicó por merced que sobre ello proueyésemos mandando que, pues el caso hera tan grave, mandásemos nonbrar vn juez syn sospecha para que a su costa fuese a faser pesquisa de lo suso dicho, e le fisiese conplimiento de justiçia.

${ }_{19}$ AGS, Registro General del Sello (en adelante RGS), Diciembre 1500, 305, 24-12-1500. Francisco de Peñalver era vecino de Granada, y en años posteriores aparece ligado al negocio de la renta. Así, en 1503 aparece junto al también granadino Gonzalo Martínez como receptor de la renta de la seda de los partidos de Guadix y Baza, cuya recaudación atravesaba dificultades después del levantamiento mudéjar de 1500-1501. Cf. García GÁmez, "La renta”, p. 264.

${ }^{20}$ Para las compañías financieras castellanas me remito al estudio de ORTEGA CERA, "Estrategias". Para la participación de otros genoveses en este tipo de compañías me remito a los datos sobre Ambrogio Spinola, vecino de Granada, en GonZÁlez ArÉvalo, "De las postrimerías", pp. 260-266.

${ }^{21}$ AGS, RGS, Octubre 1502, s.f., 24-X-1502. Publicado en García Valverde, Moreno Trujillo y de La Obra Sierra, Diplomatario, doc. 232. 
Resulta evidente la seguridad que sentía Santoyo, que no sólo muestra su enfado por las explicaciones que le exige en público Grimaldi, sino que incluso le propina una bofetada, agresión ante la que el bachiller Calderón no hizo nada. Más aún, el alcalde de la ciudad tampoco aprovecha para detenerlo cuando Santoyo se cambia de una iglesia a otra, lo que hace sospechar que se había acogido a sagrado para eludir problemas con la justicia ordinaria ${ }^{22}$.

\section{LA ESTANCIA EN LA CORTE (1503-1508)}

Comoquiera que finalizara la cuestión, lo cierto es que los acontecimientos pronto llevarían a Francesco Grimaldi fuera del Reino de Granada. Efectivamente, coincidiendo con la concesión de un poder en marzo de 1503 al también genovés Juan de Gra para que se ocupara de todos sus asuntos en la ciudad de Granada ${ }^{23}$, comienzan a aparecer informaciones sobre su desplazamiento a la Corte. Con toda probabilidad, una vez más, la presencia de su primo, Agustín Italián, fue una de las principales razones para acudir a ella ${ }^{24}$. El traslado coincidiría con la marcha, en principio definitiva, de Pantaleón Italián a Italia y el establecimiento de Agustín de forma permanente en la Corte, ocupándose el tercer hermano, Gaspar, de las operaciones realizadas desde Málaga ${ }^{25}$. Es por tanto en este momento cuando Agustín y Francesco debieron formar una compañía y empezaron a actuar de manera conjunta ${ }^{26}$. Desde luego, en la documentación analizada su nombre siempre aparece asociado al de su primo. Y parece claro que, a diferencia de Agustín, Francesco no se desplazó ocasionalmente al Reino de Granada, sino que residió de manera permanente en la Corte, pues su nombre desaparece de los protocolos notariales de Málaga y Granada en estos años.

En consecuencia, se entiende que la estancia en la Corte fue prolongada, siempre ligada a operaciones financieras. Así por ejemplo, en diciembre de 1503 el tesorero Alonso de Morales recibía órdenes de entregarle a él y a Agustín Italián una cantidad indeterminada que debían entregar en Inglaterra al doctor Rodrigo González de la Puebla, embajador de los Reyes Católicos ante Enrique VII Tudor ${ }^{27}$. Entre sus contactos también se encontraba Cristóbal Colón. Efectivamente, el Almirante escribía a

\footnotetext{
${ }^{22}$ Como miembro destacado de la oligarquía ciudadana, el bachiller Juan de Santoyo era una persona muy importante en Jaén. No sólo estaba emparentado con los oidores de la justicia, posteriormente sería una de las figuras clave en la derrota del movimiento comunero en la región en 1520. Además era un hombre acaudalado, como se deduce del memorial presentado para exigir reparaciones porque sus propiedades habían sido objeto del asalto de los comuneros. Cf. Díaz DE LA GuARDia y LóPEz, "La guerra de las comunidades".

${ }^{23}$ Se conserva copia del poder en la sustitución que hace del mismo el citado Juan de Gra en Hernando de Huete, procurador de causas, en enero de 1512, y en la deuda que cobra en nombre de Grimaldo al mes siguiente. De la Obra Sierra, Mercaderes italianos, docs. 96 y 102.

${ }^{24}$ Para el parentesco ver supra nota 10.

${ }^{25}$ LÓPEZ de Coca CAStañer, “Genoveses en la corte”, pp. 467-468, 470-471.

${ }^{26}$ Gutierre Gómez de Fuensalida, embajador en Inglaterra, en el Memorial elaborado en 1521 sobre el pago de la dote de la infanta Catalina de Aragón, se refiere a Francesco Grimaldi como "conpañero de Agostin Ytaliano, e de su conpañía". Correspondencia, p. 588, 5-XI-1521. Resulta llamativo que en su análisis de las actividades de los hermanos Italián en la Corte - en el trabajo citado en la nota anterior- el profesor López de Coca no proporcione referencias a esta asociación.

${ }^{27}$ AGS, CC, Cédulas, 6, 228, 3, 20-XII-1503.
} 
su hijo Diego el 13 de diciembre de 1504 para que recurriera a Agustín y a Francesco para que le proporcionaran "los dineros que hobiéredes menester" 28.

Francesco Grimaldi y Agustín Italián tuvieron una participación importante en el pago de la dote de la infanta Catalina, que acaparó el grueso del servicio de 1502. Evaluada en 200.000 coronas de oro pagadas en dos plazos, el primero, inmediato al compromiso matrimonial, ascendió a 100.000 coronas y fue adelantado por esta familia genovesa ${ }^{29}$. La infanta se desposó con Arturo, príncipe de Gales, en noviembre de 1501, pero el joven consorte falleció en abril de 1502 sin haber consumado el matrimonio. Como es sobradamente conocido, se produjo una situación inesperada que se alargó por espacio de siete años: Enrique VII de Inglaterra se resistía a devolver la mitad de la dote de Catalina, que vivió virtualmente como una reclusa a la espera de contraer matrimonio con el príncipe Enrique, como finalmente acordaron los reyes de Inglaterra y Aragón. Al final el matrimonio no se produjo hasta el fallecimiento del monarca inglés y el ascenso al trono de Enrique VIII en 1509, con una nueva dote cuya entrega afrontó diversas dificultades ${ }^{30}$.

Entre tanto, parece que la posición de Francesco Grimaldi y su entorno en la Corte no se resintió durante el breve reinado de Felipe I el Hermoso. Efectivamente, el soberano borgoñón expedía una cédula en junio de 1506 por la que se dirigía a Agustín Italián -que el año anterior le habría prestado 5.000 ducados- y en ella Grimaldi figura como contino de los reyes ${ }^{31}$.

Con posterioridad el vacío documental hace difícil conocer la localización y las actividades desarrolladas por Francesco Grimaldi una vez fallecido Felipe el Hermoso en septiembre 1506. Pero cabe suponer que permaneció en la Corte, participando en operaciones financieras y ligado a Agustín Italián. Así por ejemplo, en diciembre de ese año se encontraba en Valladolid. En esa fecha el tesorero real Ruy López de Toledo otorgaba una escritura de obligación ante el escribano Lope Díaz de Castromocho por la que se comprometía a que si en el plazo de dos años no devolvía a Grimaldi 247.000 maravedíes el genovés podría hacerse con las tierras y heredades que el poderoso judeoconverso tenía en el Berbe, en el Reino de Granada, entre Moclín y Colomera ${ }^{32}$.

Asimismo, en el ambiente cortesano habría estrechado su relación con el comendador Gutierre Gómez de Fuensalida, que le llevaría consigo a Inglaterra en la embajada que tenía como objetivo el cumplimiento del matrimonio proyectado entre

\footnotetext{
${ }^{28}$ Fernández de Navarrete, Colección, p. 345.

${ }^{29}$ Carretero Zamora, "Los servicios de Cortes", p. 47.

${ }_{30}$ Para las negociaciones del matrimonio entre Catalina y Enrique me remito a Doussinague, La política internacional, capítulo XVI, pp. 283-300.

31 "Agostín Italiano. Myçer Andrea de Burgo, enbaxador del Rey my señor e mosevr de Bere, my mayordomo mayor, me fan fecho relaçión del buen deseo que tenyes de me seruir, lo qual yo fe visto por obra, e vos lo agradezco muy pues me prestastes çinco myll ducados fasta San Juan. Nuño de Gumiel, my thesorero, me a dicho como a fablado con Francisco de Grimaldo, contino de nuestra casa, para que vos tomeys a canbio estos çinco myll ducados e otros myll ducados que son menester para cosas que tocan a my seruicio". ALONSO GARCíA, El erario del reino, pp. 236-237.

32 Archivo de la Diputación de Granada (en adelante ADG), L07872, Inventario de documentos procedentes del mayorazgo de doña Francisca de Cáceres (1736), escritura del 12-XII-1506 ante Lope Díaz de Castromocho. Debo los datos aprovechados del fondo Grimaldo conservado en el archivo citado a la generosidad del colega y amigo Rafael Girón Pascual.
} 
Catalina de Aragón, viuda de Arturo de Gales, y el nuevo heredero de Enrique VII Tudor, el futuro Enrique VIII de Inglaterra.

\section{INGLATERRA (1508-1510): LA DOTE DE CATALINA DE ARAGÓN}

Las circunstancias sobre la llegada de Francesco Grimaldi a Inglaterra resultaban un tanto contradictorias hasta ahora. Garrett Mattingly en su biografía sobre Catalina de Aragón, sin citar fuente alguna, afirma que Gutierre Gómez de Fuensalida, embajador de Fernando el Católico, acudió a verle en cuanto llegó a Londres en febrero de 1508 "y escuchó las opiniones del banquero sobre la política inglesa" 33 . Semejante afirmación deja entender claramente no sólo que el banquero genovés se encontraba en Gran Bretaña antes de la llegada del embajador español, sino que debía llevar el tiempo suficiente como para estar bien informado sobre la política inglesa, lo imprescindible al menos como para que Fuensalida estuviera interesado en conocer su opinión.

Sin embargo, las fuentes españolas contradicen abiertamente esta reconstrucción de los hechos. Efectivamente, el propio Gómez de Fuensalida deja muy claro en una carta al rey Fernando que Francesco Grimaldi "vino acá conmigo"34, lo que confirma asimismo la infanta Catalina, que un año más tarde informaba a su padre de que "el enbaxador a tomado tanta afición con este mercader Francysco de Grymaldo que aquy truxo consygo" 35 . Y es el mismo embajador español quien confirma tanto la fecha de partida desde Burgos, el 6 de enero de $1508^{36}$, como la de llegada en su primera carta al monarca aragonés, escrita en Londres el 1 de marzo de 1508: "Por dos vías he escrito a vuestra magestad haziéndole saber cómo llegué a Cales a los XIII días del mes de hebrero, y a Londres a los XXII del dicho mes"37.

Algunos autores sostienen que Francesco Grimaldi contaba con parientes en Londres $^{38}$. Sin embargo, lo cierto es que llegó a la capital inglesa como factor y socio de su primo Agustín Italián para llevar con Fuensalida lo que faltaba de la dote de la infanta Catalina ${ }^{39}$. Lo confirma, una vez más, el propio embajador español al elaborar

33 Mattingly, Catalina de Aragón, p. 128.

${ }^{34}$ Correspondencia, p. 423, 11-III-1508. Al mes siguiente recordaba en otra carta al rey Fernando que Grimaldi "vino comigo". Ibidem, p. 444, 27-IV-1508.

35 AGS, Patronato Real (en adelante PR), Tratados con Inglaterra, legajo 5, f. 59, 9-III-1509. Publicado en "Queen Katharine: March 1509, 1-15”, pp. 13-22.

${ }^{36}$ La fecha de partida y la duración del viaje las da Fuensalida en la Quenta con el secretario Almaçan, de mi salario: "Partí de Burgos para yr a Yngalaterra a seys días del mes de enero del año de mill e quinientos e ocho. Tardé en el viaje diez e nueve meses e diez días". Correspondencia, pp. 591-592.

37 Ibidem, p. 414.

38 Así por ejemplo Thomas Penn, que sin citar fuente alguna afirma que Francesco Grimaldi era primo de Giovanni Battista Grimaldi, bien conocido por su relación con el aristócrata Edmund Dudley, administrador, agente financiero y consejero privado de Enrique VII. Cf. PenN, Winter King, pp. 317 y 336. Giovanni Battista Grimaldi era hijo de Lodovico Grimaldi, y ambos representaron el banco familiar, de origen genovés, en Londres, como confirma BRATCHEL, "Italian Merchant Organization", p. 16.

${ }^{39}$ Esta información contradice frontalmente la tesis de los historiadores ingleses que sostienen que Francesco Grimaldi representaba el banco familiar en la capital inglesa. Más aún, los registros ingleses del Public Record Office no han permitido confirmar tampoco relación de parentesco alguna entre Francesco Grimaldi 
en 1521 el Memorial del dinero que se llevó a Yngalaterra, e se tomó allá a canbio para pagar el dote de la señora Princesa de Gales ${ }^{40}$.

Primeramente llevó Francisco Grimaldo, fator e conpañero de Agostin Ytaliano, e de su conpañía, sesenta e çinco mill ducados que los sobredichos se obligaron a pagar en Londres para el dote de la señora Princesa de Gales LXVM ducados.

Yten, le enbiaron después al dicho Francisco de Grimaldo diez mill ducados en oro; llevóselos Montenegro, criado de Agvstín Ytalián, y entregóselos al dicho Francisco de Grimaldo XM ducados.

Los quales dichos setenta e cinco mill ducados syenpre estovieron a cargo del dicho Francisco de Grimaldo e de su conpañía.

En las próximas líneas se pondrá en evidencia que la actuación de Francesco Grimaldi en la embajada castellano-aragonesa a Inglaterra en 1508 fue un perfecto exponente del papel de los genoveses en la Monarquía Hispánica de los Reyes Católicos y los primeros años de Carlos I, cuando se ocupaban principalmente de la financiación de embajadas y traspasos financieros en Europa ${ }^{41}$.

La correspondencia de Gutierre Gómez de Fuensalida con el monarca aragonés no deja lugar a dudas sobre su aprecio personal al banquero genovés - a quien no duda en recomendar- y a su labor para llevar a buen término el pago de la dote, protegiendo los intereses de Fernando el Católico frente al taimado Enrique VII. Así en marzo de $1508^{42}$ :

Yo he comunicado acá con miçer Françisco Grimaldo, conpañero de miçer Agvstín, que vino acá comigo, para pagar los LXVM escudos, sy por ventura me faltasen diez o doce mill ducados, sy podría dar forma de los pagar acá por vuestra alteza. Es muy buen onbre e desea mucho seruir a vuestra alteza, y respondióme que avnquel supiese perder IIM ducados en XM ducados, que porque vuestra alteza pudiese conplir, y porque en este otro negoçio por defeto de la paga no ovyese ynconviniente, que asegurando vuestra alteza allá que lo quel tomase acá para conplir lo que faltase, quel haría lo posyble en todo. Escríuolo a vuestra alteza para que por vna çédula se lo agradezca, y sy fuere menester, lo ponga por obra.

La empresa se revelaría más ardua de lo que prometía al principio. En este proceso de tira y afloja Francesco Grimaldi se revela como la mano derecha de Fuensalida en Inglaterra. Así, en mayo de 1508 el embajador escribía al rey Fernando ${ }^{43}$ :

La çédula de cambio que vuestra alteza mandó enbiar tengo secreta, que no lo sabe syno Françisco Grimaldo, que la ha de pagar; el qual la reçibió de buena voluntad, y dize que no solamente la pagará a XX días vista, como la çédula dize, mas que sy

\footnotetext{
de una parte, y Lodovico y Giovanni Battista Grimaldi -padre e hijo- o Benedetto y Goffredo Grimaldi -hermanos- de otra. Bratchel, "Italian Merchant Organization", p. 16.

${ }^{40}$ Correspondencia, pp. 588-589, 5-XI-1521.

${ }^{41}$ En este sentido resulta muy interesante el análisis de Alonso García, "Genoveses en la Corte".

${ }^{42}$ Correspondencia, p. 423, 11-III-1508.

${ }^{43}$ Ibidem, p. 450, 9-V-1508.
} 
luego fuere menester, que luego la pagará, y que por seruir a vuestra alteza, sy por caso más fuese menester, quel saldría aquí al rey de Inglaterra por le pagar todo quanto sus fuerças alcanzaren, y le dará fianças a su contentamiento de le pagar al tienpo que con él pusyese y vuestra alteza mandase; y bien creo yo que estos se contentarían sy vuestra alteza saliese a pagar en dinero como ellos quieren de dar plazo, y avn de vn año, dándoles seguridad de la paga; y tanbyén dize Francisco Grimaldo, que sy será menester que se tome a canbio o en qualquier manera que vuestra alteza lo mandare, o lo que yo en nonbre de Vuestra alteza le dixere, que todo lo hará.

Comoquiera que fuera, Fernando el Católico, preocupado por la situación de su hija, procuraba cumplir la dote acordada para el nuevo matrimonio con el príncipe Enrique, pendiente desde que en 1503 se asentaron las capitulaciones para el nuevo enlace $^{44}$. Y en agosto de 1508 se dirigía a Grimaldi para comunicarle que por una carta de Fuensalida había conocido la oferta del genovés de poner lo que faltaba para cumplir con los 100.000 escudos de oro correspondientes a una parte de la dote de la infanta Catalina, prometiéndole que le pagaría las cédulas de cambio que le enviara correspondientes a esa cantidad ${ }^{45}$.

Con todo, el pago de la dote seguía sin cumplirse. Los ingleses reaccionaron mal ante el giro que tomaban los acontecimientos, prohibiendo que ni Fuensalida ni Grimaldi abandonaran el país, en represalia porque ambos seguían sacando de Inglaterra a Brujas el dinero de la dote, como revela claramente otra carta del embajador español al rey Fernando desde Londres en noviembre de $1508^{46}$ :

Asymismo soy avysado que no dexarán salir daquí a Francisco Grimaldo ni a mí, puesto quel casamiento no se haga. No dixeron el porqué; mas presumo que es la causa que deven aver sabido quel dicho Francisco poco a poco saca de aquí el dinero y lo

${ }^{44}$ Las condiciones pactadas para el segundo matrimonio eran menos ventajosas para los Reyes Católicos, impelidos por la necesidad de contar con el apoyo de Enrique VII en la guerra que les enfrentaba a Luis XII de Francia. Rodrigo González de Puebla había conseguido mantener el compromiso matrimonial en circunstancias adversas y había defendido los intereses de Fernando de Aragón, pero el giro dado a las relaciones anglo-españolas por Gutierre Gómez de Fuensalida dificultó extremadamente el desarrollo último de las negociaciones, finalmente desbloqueadas por el fallecimiento del primer monarca Tudor el 21 de abril de 1509. MattingLY, "The Reputation", pp. 39-41.

45 "El Rey. Francisco de Grimaldo, por letras del comendador de la Membrilla, mi embajador, he sabido con cuanto amor y afección ofrecéis de cumplir allá, siendo menester lo que falta para cumplimiento de cien mil escudos, en dinero contado, para la paga de la dote de la Serenísima Princesa de Gales, mi hija, sobre el dinero que ya allá tenéis para ello, lo cual vos agradezco y tengo mucho en servicio y en cosas que toquéis a vuestro bien y honra, espero de vos satisfacer y confiando de la dicha oferta que habéis hecho a mi embajador". AGS, PR, c. 54, doc. 85, 7-VIII-1508. Transcripción tomada de Pulido BuENo, La familia genovesa, pp. 7273. Este autor confunde a nuestro genovés, Francisco Grimaldi, con Juan Francisco de Grimaldo, afincado en Sevilla.

46 Correspondencia, p. 495, 6-XI-1508. El envío del dinero a los Países Bajos en otra carta de Fuensalida a Fernando de Aragón del 20 de marzo de 1509: "Temiendo que si este Rey [Enrique VII] sintiesse que vuestra alteza mandava que se demandasse la princessa si no quisiesse facer el casamiento, como lo ha sentido y sabido por el poco secreto que ay en la cámara de la princessa, yo dixe a Francisco de Grimaldo que poco a poco sacasse el más dinero que pudiesse y assy lo ha fecho, que bien ay fuera de Ynglaterra mas de XXXM coronas y todo estotro se sacará poco a poco y se pondrá en lugar que si menester fuere para fazer el pago al Rey de Ynglaterra pueda bolver aquí sin inconviniente ninguno. Esto he fecho por assegurar mi coraçón que según lo que aqua sentía y siento me parecía que se devía assí fazer”. AGS, PR, Capitulaciones con Inglaterra, legajo 5, s.f., cifrado, 20-III-1509. Publicado en "Queen Katharine: March 1509, 16-31”, pp. 23-34. 
pasa a Brujas, y tyene bien cerca de quinze mil ducados fuera. No lo sabe esto Francisco Grimaldo, que por no alteralle no se lo e osado dezyr, como quiera que ya esta acá arraygado, porque se a casado con vna muger de cámara de la prinçesa.

La poca mano izquierda de Fuensalida y su política de firmeza, opuesta a la ductilidad y la diplomacia desplegada por Puebla, prácticamente llevaron a una ruptura de las relaciones diplomáticas entre Inglaterra y Castilla-Aragón al año de haber llegado $^{47}$. La situación seguía enquistada en febrero de 1509, como revela una carta del rey Fernando a Gutierre Gómez de Fuensalida contenida en un cedulario de Miguel Pérez de Almazán ${ }^{48}$. El rey escribió también a Francesco Grimaldi directamente en el mismo sentido, esto es, ordenándole que de los 75.000 ducados de la dote se entregaran 40.000 ducados a Lorenzo Locavela o a Bautista y Bartolomé Lomelín. Unos días más tarde, el 10 de marzo, Fernando el Católico insistía de nuevo en otra carta en el mismo sentido al embajador Fuensalida. Y el 4 de abril se dirigía otra vez al diplomático para ordenar además que del citado dinero se entregaran 20.000 ducados al florentino Andrea Vellutti, vecino de Medina del Campo, "por çierta contrataçión que con él se hizo", teniendo que entregarlos a Pedro López de Calatayud, estante en Brujas, o en su ausencia a Fernando de Daza, estante en Londres ${ }^{49}$.

En consecuencia, en primavera de 1509 Fernando de Aragón no disponía de liquidez para pagar la dote, pero quería entregar la cantidad pendiente para que se llevara a cabo el casamiento. De este modo, como Rey Gobernador y Administrador de Castilla negoció la concesión de un nuevo préstamo de 65.000 ducados con el banquero genovés Agustín Italián, que los pagaría en Londres a la persona que se le indicase. Como garantía de dicha cantidad el ligur recibiría la corona rica y un collar de oro con piedras y perlas que habían pertenecido a la reina Isabel. Las joyas respondían al préstamo de los 65.000 ducados para cubrir la dote de la infanta Catalina, que ascendía a 100.000 escudos de oro, cantidad que se completó con otro préstamo que en mayo de 1509 hicieron in solidum los también mercaderes y banqueros genove-

47 Mattingly, "The Reputation”, p. 40.

48 "Gutierre Gómez de Fuensalida, comendador de la Hembrilla, mi embaxador en Inglaterra: Ya sabéis cómo Francisco de Grimaldo tiene allá el dinero que Agostín Italián está obligado a dar para el casamiento de la serenísima Princesa de Galiz, mi hija, para acudir con ello a vos o a la persona que yo mandare. Y porque del dicho dinero yo he mandado que se dé a Lorenzo Locavela o Bautista y Bartolomé Lomelins, quarenta mil ducados: Por ende yo vos mando que recibáys luego del dicho Francisco de Grimaldo todo el dicho dinero, y para ello le daréis una mi carta que aquí os envío, para que os acuda con todo ello; y dad y pagad luego al dicho Lorenzo Locavela, o Bautista e Bartolomé Lomelines los dichos quarenta mil ducados que yo le mando dar, y tomad su carta de pago". RodríGUEZ ViLla, "Un cedulario", doc. 443.

${ }^{49}$ Ibidem, docs. 444, 472, 543. Explica claramente los motivos Fuensalida en el Memorial de 1521: ante el temor de que Enrique VII se quedara con la dote de la infanta Catalina sin celebrar el matrimonio con el príncipe de Gales, el embajador español, siguiendo instrucciones del rey Fernando, ordenó a Francesco Grimaldi que entregara a Lorenzo Lecabela y su compañía 40.000 ducados de los 75.000 que había recibido en Londres, quedando en poder de nuestro genovés los 35.000 ducados restantes: "Destos setenta e çinco mill ducados, por algund reçelo que se tovo que el Rey de Yngalaterra los tomarya syn concluyr el casamiento de la señora Princesa de Gales, el Rey, nuestro señor, mandó que se sacasen de Yngalaterra, e por çédula de su alteza dada a la conpañía de que era fator e conpañero Lorenço Lecabela, mandó dar al dicho Lorenço Lecabela quarenta mill ducados, los quales le dio el dicho Françisco de Grimaldo, y la carta del contento del dicho Lorenço Lecavela de cómo reçibió los dichos quarenta mill ducados, se enbió luego al Rey, nuestro señor, porque ansy lo enbió a mandar XLM ducados.Quedaron en poder del dicho Francisco de Grimaldo treynta e çinco mill ducados XXXVM ducados". Correspondencia, p. 589, 5-XI-1521. 
ses Francesco Grimaldi, Agustín (Agostino) Vivaldo y Nicolás Lomelin (Lomellino), que se comprometieron a pagarlos al rey de Inglaterra, recibiendo la cuantía en Castilla mediante cédulas de cambio que les daría el embajador Gutierre Gómez de Fuensalida. Los ligures pagaron el dinero en Londres en junio de 1509, con ocasión de la celebración del matrimonio entre Catalina y Enrique VIII el 11 de ese mismo mes, poco después del fallecimiento de Enrique VII, acaecido el 21 de abril de ese mismo año $0^{50}$.

El Memorial firmado por Fuensalida en 1521 no sólo detalla el modo en que se procedió al pago, tal y como se había acordado entre las partes en mayo de 1509, sino que revela, una vez más, el papel de Francesco Grimaldi a la hora de hacer efectiva la dote. Más aún, nuestro genovés fue el encargado de pagar a los correos que se despacharon para Castilla, incluyendo el que "levó la nueva que hera concluso el casamiento" "51. y de adelantar 200 coronas a cuenta de los 2.320 ducados que el embajador debía cobrar de su salario, descontadas de las 700 coronas que quedaron en poder del genovés ${ }^{52}$.

\section{INGLATERRA (1508): EL MATRIMONIO CON FRANCISCA DE CÁCERES}

Como revela una carta de Fuensalida al rey Fernando de noviembre de 1508, en esa fecha Francesco Grimaldi "ya esta acá arraygado, porque se a casado con vna muger de cámara de la prinçesa" ${ }^{53}$. De modo excepcional, el matrimonio de Grimaldi está ampliamente documentado por sus inusuales circunstancias. La dama de Catalina de Aragón era Francisca de Cáceres, a quien Mattingly describe, tal vez de modo un tanto fantasioso, como "la más alegre de las damas de Catalina de Aragón, princesa de Gales, y su favorita sólo detrás de María de Salinas. De todas las damas era la que lo pasaba peor y la intrigante más activa de la camarilla que quería volver a España, lo que provocó el alejamiento de Catalina. Eso la convirtió en la principal enemiga del confesor de la princesa, fray Diego, el más firme defensor de que aguantara en su posición en Inglaterra. A su vez, Francisca de Cáceres le veía como el principal obstáculo para abandonar una Inglaterra que encontraba deprimente" ${ }^{44}$.

No hay muchas informaciones sobre la camarera de la infanta Catalina. Ni siquiera está clara su ascendencia. En la carta de arras que le concede su marido en octubre

\footnotetext{
${ }^{50}$ CODOIN, 1, p. 359; Prieto Cantero, “¿Dónde están el collar”, II, pp. 219-221.

51 "Concluyóse el casamiento de la señora Prinçesa de Gales, con asyento que se pagase luego dentro de ocho días después de concluydo el casamiento çinquenta mill coronas. Este asyento fue fecho en el mes de mayo de quinientos e nueve años, a que el día de san Migel venidero del dicho año se pagasen las otras çinquenta mill coronas, e para seguridad de la paga se diesen fianças llanas e abonadas de mercaderes, para que al tienpo pagasen las dichas çinquenta mill coronas; e para hazer la primera paga de las dichas cinquenta mill coronas que se ha de hazer de presente, se tomaron a canbio quinze mil ducados de Laquin de Vibaldo, e Dominico Lomelin, e con los treynta e çinco mill ducados que tenía el dicho Françisco de Grimaldo, fueron cinquenta mill ducados, razonados a çinquenta e tres dineros, hechos coronas, montaron çinquenta e tres mill coronas, razonada la corona a cinquenta dineros................................. IIIIM coronas". A continuación Fuensalida detalla cómo se procedió a la segunda paga de la dote. Cf. Correspondencia, pp. 589-591.

${ }^{52}$ Ibidem, pp. 591-592, 5-XI-1521.

${ }^{53}$ Ibidem, p. 495, 6-XI-1508.

${ }^{54}$ Mattingly, Catalina de Aragón, p. 143.
} 
de 1510, el documento más fiable por menos sospechoso de manipulación, se dice que es hija de Bartolomé de Cáceres ${ }^{55}$. En consecuencia, lo único que está claro es que acompañó a Catalina a Inglaterra para su primer matrimonio con el príncipe Arturo. De hecho, la camarera de la nueva princesa de Gales fue una de las fuentes en las que se apoyó la teoría de la no consumación del enlace. Efectivamente, don Juan de Gamarra, castellano, Justicia mayor y corregidor de Logroño, Calahorra, Alfaro y sus territorios, en la declaración contenida en el expediente de divorcio de 1531 recordó que había acompañado a doña Catalina a Inglaterra como paje. Gamarra estuvo de servicio en la antesala de la alcoba regia la noche de bodas, y al entrar en las habitaciones de la princesa a la mañana siguiente encontró a las damas del séquito preocupadas por la infanta y decepcionadas con el príncipe. Así, afirmaba que precisamente Francisca de Cáceres, con la que mantenía excelentes relaciones y a la que recuerda como encargada de vestir y desvestir a la princesa española, se mostraba triste, diciendo a las otras damas de compañía que nada había ocurrido entre los cónyuges aquella noche, lo que causó sorpresa entre quienes la escucharon, burlándose del príncipe de Gales ${ }^{56}$.

Las circunstancias en las que se celebró el matrimonio en otoño de 1508 no están del todo claras, y el cruce de acusaciones y justificaciones entre Catalina de Aragón y Gutierre Gómez de Fuensalida hace complicado establecer la veracidad de los he$\operatorname{chos}^{57}$. La princesa viuda de Gales, muy influenciada por su confesor, fray Diego, escribió a su padre en marzo de 1509 para quejarse de la torpeza del embajador español, que en su opinión mal servía a los intereses del rey aragonés y a los suyos propios en Inglaterra. En esa carta no sólo habla de la cercanía del diplomático con Francesco Grimaldi, como ya se ha visto; asimismo da una versión muy detallada de cómo había tenido lugar el matrimonio del banquero genovés con su camarera, en contra de su

${ }^{55}$ De la Obra Sierra, Mercaderes italianos, doc. 61, 16-X-1510. En los Árboles de costados de la nobleza española del siglo XVII aparece como hija de Fernando Ibáñez y de doña Elvira de Cáceres, sin más referencias a su filiación. Cf. Salazar y Castro, Árboles de costados, p. 215. El libro proporciona asimismo una información errónea al citar a Francesco Grimaldi como "embaxador del Rey Católico à Inglaterra". Por otra parte, un Memorial plagado de inexactitudes, probablemente falsedades para elevar la cuna de los Grimaldo de Cáceres, afirma que era hija de Fernando Yáñez y de doña Elvira de Cáceres, nacida en Segovia. Para muestra de los errores, la afirmación de que Francesco Grimaldi era segundogénito del Príncipe de Mónaco y habría llegado a la Península en 1505 en una galera para servir a Felipe el Hermoso, cuando en realidad, como se ha visto, ya estaba en Granada en 1496. Real Academia de la Historia (en adelante RAH), 9/317, fols. 86r87r. Agradezco de nuevo el conocimiento del Memorial y la información de su contenido al colega y amigo Rafael Girón Pascual.

56 "Extracto del expediente seguido en Zaragoza entre doña Catalina de Aragón, reina de Inglaterra, y su marido Enrique VIII, ausente y en rebeldía, para cumplimentar un exhorto o letras remisoriales de Roma sobre la validez del matrimonio de aquellos monarcas; extracto de la copia que se halló en el archivo del monasterio de Veruela, publicado por el dignísimo académico D. Vicente Lafuente, a cuya buena amistad y generosa erudición me declaro obligadísimo", Crónica del Rey Enrico, pp. 335-336; TremLetT, Catherine of Aragon, p. 89. Sobre la estancia de Francisca de Cáceres y el entorno judeoconverso de la Corte de Catalina cf. Girón PAScual, "Francisca de Cáceres".

${ }^{57}$ Sobre lo que no hay duda, sin embargo, es sobre la fecha de celebración del matrimonio. La data de la concesión de la carta de arras, octubre de 1510, no es la fecha del enlace, como afirma Ildefonso Pulido, que confunde de nuevo a Francisco con Juan Francisco de Grimaldo. Este error se multiplica porque le lleva a situar al segundo, arraigado en Sevilla como ya se ha visto, como marido de Francisca de Cáceres. Cf. PuLIDo Bueno, La familia genovesa, p. 74. Desafortunadamente, la confusión ha llevado a error a otros autores que le han seguido, como ocurre en Alonso García, "Genoveses en la Corte”, p. 265. 
voluntad, aunque obligada a disimular para evitar el escándalo. Acusa directamente a Fuensalida de favorecer el enlace y al banquero genovés de avaricia y de amenazarla con llevarse el dinero de su dote si no hacía efectivo el pago de la dote concedida a Francisca de Cáceres por una cédula. Por todo ello habría expulsado a la camarera de su casa, siendo acogida en la suya por el embajador, que a su vez habría justificado su proceder ante la princesa viuda de Gales por las intromisiones de fray Diego en los asuntos de su embajada ${ }^{58}$.

Los historiadores británicos en general dan crédito a la versión de Catalina de Aragón sin discusión, sin valorar de manera crítica el papel del confesor de la infanta, fray Diego ${ }^{59}$. Además, no recurren a la correspondencia de Gómez de Fuensalida para reconstruir los hechos. Por mi parte, el proceder del embajador, procurando el mejor servicio para los intereses de la monarquía, así como su mayor perspectiva y el juicio emitido en su narración de los acontecimientos me inclinan a dar mayor credibilidad a su deposición. Se trata de una impresión reforzada por el testimonio del sustituto de Fuensalida como embajador en Inglaterra, don Luis Carroz, que en mayo de 1510 llega a referirse al fraile diciendo que "no he visto más mala persona en mi vida" ${ }^{60}$. Por su parte el propio monarca, convencido de la mala influencia que fray Diego ejercía sobre su hija, no cejó en su empeño para sustituirlo como confesor.

En consecuencia, Fuensalida no sólo se defiende frente a las acusaciones de la infanta, sino que en una carta coetánea igualmente dirigida a Fernando el Católico, acusa al confesor de Catalina de pergeñar la boda como estrategia para alejar a Francisca de Cáceres de la princesa de Gales por su ascendiente sobre ella, y de este modo aumentar su influencia sobre la infanta. Princesa y confesor habrían insistido sobre la conveniencia del matrimonio a Francesco Grimaldi hasta que aceptó. Y para apoyar su versión Fuensalida adjuntaba una carta de fray Diego -aunque no ha sobrevivido con la misiva al rey aragonés- y reproducía conversaciones sostenidas tanto con el confesor como con el genovés:

(...) El fraile, como no pudo por esta manera entrar en tener parte de los negoçios, porque vna Francisca de Cáceres, que entonces era el todo de la casa de la Princesa, y aun de su persona, se lo estorbaba, como conocía su ambición y soberbia y liviandad,

\footnotetext{
58 "No me parece que es raçon dexe de azer saber a V[uestr]a Alteza quan malamente el enbaxador se avydo con el en lo qual mucho me a enojado por que en este caso a ido contra el servycyo de V[uestr]a Alteza y la causa a sydo porque el enbaxador a tomado tanta aficion con este mercader Francysco de Grymaldo que aquy truxo consygo y con una my cryada Francysca de Caceres en tanta manera que ellos al fyn con su fabor se ubyeron de casar contra toda my voluntad mas como estoy de tal manera ubelo de dysymular por la onrra y onestydad de my casa y vyme en tanto estrecho que dy una cedula de suma de dyneros a mas no poder y vyen creo si V[uestr]a Alteza supyese lo que a ello me movyo sy toda my camara le mandara no me culpara mas antes me lo ternya a echo de cuya fija soy y por el enojo que esta mujer me a echo yo la eche de my casa y el enbajador de V[uestr]a Alteza la a tomado en la suya y a su mesa que aun por lo que toca a su ofycio en representar la persona de V[uestr]a Alteza no me a parecydo vyen echo. Ame echo tantos synsabores con este mercader cada dya queryendo darme a entender que se querya yr y llevar el dynero del dote syno le enpezaba a dar algo de lo que le promety de lo qual no le devo nada sy byen se myra my letra y porque my confesor desto todo me avyso el enbaxador tomo tema con el y de que conoce quan sin raçon esto a echo por escusarse dyce agora que el dycho my confesor se ponya a entender en su enbaxada". AGS, PR. Tratados con Inglaterra. Legajo 5. f. 59, 9-III-1509. Publicado en "Queen Katharine: March 1509, 1-15”, pp. 13-22.

59 Sirva de ejemplo Mattingly, Catalina de Aragón, pp. 143-145.

${ }^{60}$ Correspondencia, p. XCI.
} 
púsose el fraile en pensar que si el echaba a la Francisca de Cáceres de la gracia de la Princesa, quel haría de la Princesa a su voluntad. Y de todo esto estaba yo inocente, y el fraile no cesaba de poner sienpre a la Princesa en mala grazia conmigo, y ya yo sentya alguna tibieza en la Princesa, y no podía pensar qué fuese; y el fraile halló lo que deseaba para echar fuera a Francisca de Cáceres, que le era todo el inpedimento para lo quel deseaba, y púsose por casamentero entrella y Francisco de Grimaldo, y siguióle tanto hasta que le venció, lo qual Vuestra alteza vera por esta carta de fray Diego que les envío; y la Princesa le hizo muchos ofrecimientos, y en su presencia se desposó; y estaba la Princesa tan contenta, que no pensaba que avía hecho poco, y yo dixe a su alteza primero que les desposasen, que su alteza lo devía decir al Rey de Ynglaterra, y que no lo debía de hazer sin su sabiduría, pues estaba dentro en su casa. La Princesa me agradeció mi consejo, mas no le plugo dello al fraile, y la Princesa dixolo luego al Rey de Ynglaterra, y al Rey le plugo y hizieronse los desposorios en la cámara de la Princesa ${ }^{61}$.

No se puede descartar que una de las razones del ligur para aceptar el matrimonio, más allá de las presiones evidentes que recibió, fuera la elevadísima cantidad con que fue dotada la camarera de la infanta, a pesar de la recomendación de Fuensalida a Grimaldi de que se contuviera en su petición. En contra del criterio del embajador, Catalina de Aragón dotó a su dama con 4.000 ducados, el doble de lo que solía su madre, la reina Isabel, lo que en opinión de Fuensalida creaba un precedente peligroso de cara a los matrimonios que aún debería concertar y dotar la infanta para las otras damas de su séquito ${ }^{62}$.

Tampoco había acuerdo sobre dónde velar a los novios: la infanta quería hacerlo en palacio, pero Fuensalida la convenció de que, dada su situación, no era conveniente, y se ofreció a hacerlo en su propia casa. Por su parte, fray Diego, como impulsor del matrimonio, quiso encargarse asimismo de ello, pero tropezó con la oposición de los

${ }^{61}$ Ibidem, pp. 534-536.

62 Ibidem: “(...) Trabajó el frayle que se velasen Francisco de Grimaldo y Francisca de Cáceres, y la Princesa enbyóme a dezir que yo dixese a Francisco de Grimaldo que se velase luego, y yo díxeselo, y él no quisiera hazello hasta que la Princesa se casase; mas el frayle aquexo tanto a la Princesa para que lo mandase y al Francisco de Grimaldo para que lo hiziese, que traya una pena consygo que no reposaba noche ni día, y el Francisco de Grimaldo díxole: “CCómo me tengo de casar, que no sé lo que la Princesa a de hazer conmigo ni con mi muger?" Díxole el frayle: "Hazed una cédula, que la Princesa os la firmará, de toda la cantidad que quisiéredes, y no estéys por eso, que no ay oficio en su casa ni cosa que vos pydáys que no se os de". El Francisco de Grimaldo dyxome lo quel frayle le dyzía. Yo le dixe que no se enlevase que se hyziese la cédula de manera quel fuese cierto que era para pagar lo que le prometiesen, y que no hyziese daño a la Princesa. Fynalmente, que el frayle y él hycieron su cédula, y prometióle la Princesa por ella dele dar quatro mil ducados en casamiento a Francisca de Caceres; y sy el Francisco de Grimaldo quisiera que pusieran seys y ocho mil, tantos pusiera el frayle. Dada la cédula, el Francisco me la mostró. Yo torné al frayle y díxele: "Mal aconsejada es la Princesa en muchas cosas que haze, y desto vos tenés la culpa. No dyvuera su alteza de dar tal cédula como dio por dos cosas; la una, que sy la dyo para no pagalla, no la dyvvera de dar; sy la dyo para pagalla, ecedio de la razón, porque a vna mujer de cámara, nunca la Reyna, nuestra señora, llego a dalle dos mil ducados, y diviérades de mirar que le quedan a la Princesa damas y otras mugeres de cámara que a de casar, y si a esta, que era muger de cámara, mandó quatro mil ducados, ¿qué le demandarán con las damas sy ovieren de casar en esta tierra?". Respondióme: "No lo hize yo". Díxele: "Vos lo hizistes, y consejastes mal a su alteza". Dixo: "No es syno que todo lo que yo hago os parece mal". Fuese a la Princesa y díxoselo. La Princesa salió luego con yra y dixo algunas palabras de mí; mas esto no era nada". 
contrayentes, que ante la imposibilidad de verlarse en palacio optaron por hacerlo en casa del embajador ${ }^{63}$.

El nuevo desarrollo de los acontecimientos contrarió tanto al fraile que el mismo día de la boda discutió en público con la novia, hasta el punto de que Francisca de Cáceres no se quiso confesar con él y lo hizo con el confesor del rey de Inglaterra. Esta afrenta constituyó una ruptura de hostilidades en toda regla entre el fraile y la camarera, y probablemente sea el origen de la animadversión desarrollada por Catalina, fuertemente influida por su confesor, hacia su antaño favorita, a la que Fuensalida se refería como su "priuada" ${ }^{64}$. Así se explican los términos tan duros en los que la infanta refirió la boda cinco meses después de su celebración, como se ha visto. Cabe suponer que fue entonces cuando la princesa viuda de Gales acusó al embajador de haber obrado en contra de su deseo y de haber acogido en su casa a una dama que ella había echado de la suya. Fuensalida se defendió argumentando que había obrado para proteger a la princesa, sin que ésta le hubiera hecho saber en modo alguno su contrariedad ${ }^{65}$.

El deterioro de la situación es palpable tanto en la reclamación de Francesco Grimaldi del pago íntegro de la dote de su mujer como en su determinación de marcharse de Inglaterra. El genovés, que tenía alquiladas dos estancias en la casa del embajador y se había instalado en ellas con su mujer, se mostraba irritado ante Fuensalida, que buscaba calmarle junto con Francisca de Cáceres por todos los medios. En ese momento al estado de ánimo probablemente también contribuía el estancamiento de las

${ }^{63}$ Ibidem: “(...) Trabajó el frayle que se velasen Francisco de Grimaldo y Francisca de Cáceres, y la Princesa enbyóme a dezir que yo dixese a Francisco de Grimaldo que se velase luego, y yo díxeselo, y él no quisiera hazello hasta que la Princesa se casase; mas el frayle aquexo tanto a la Princesa para que lo mandase y al Francisco de Grimaldo para que lo hiziese, que traya una pena consygo que no reposaba noche ni día. (...) Vino el tienpo del velarse los dichos Francisco y Francisca. La Francisca, como priuada de la Princesa, quisiera se velar en palacio, i la Princesa escribiómelo. Yo le escreby que me parecía que no se debía hazer en palacio, porque su alteza no estaba de manera que pudiese hazer semejantes fiestas, y que fuesen como a su estado pertenecía, mayormente estando metida casa del Rey; que se hiciese fuera de palacio, y que por servilla, yo tomaría el cargo, y en mi casa se velarían y yo les daría la comida. Plúgole a la Princesa; mas no le plugo al fraile, y trabajó que fuesen a velarse a un villaje, y que él les daría de comer, que pues él los había casado, que el quería gozar de aquella onrra. El Francisco de Grimaldo y la Francisca de Caceres no lo quisieron hacer, sino que pues en palacio no avía de ser, que querían venirse a mi casa".

${ }^{64}$ Ibídem: “(...) Vino el día de las bodas, y el fraile y la Francisca de Cáceres riñeron delante de la Princesa, y por esta rencilla la Francisca de Cáceres no se quiso confesar con el fraile, y confesóse con el confesor del Rey de Ynglaterra, que es de la orden de San Francisco. Fue esto tanta injuria para el fraile, que hizo bramuras como loco; de manera que hizo a la Princesa estar tan mal con la Francisca de Cáceres, que la enbyó aquel día que se vbo de velar como si ubiera hecho maldad en su casa, y vinieron y veláronse en mi casa. Dexo esto, porque todo esto fue principio de lo que después ha sucedido".

${ }^{65}$ Ibidem: “(...) Desta manera e estado cinco meses. (...). [La Princesa] lo más que me dixo, que avía recebido en mi casa a Francisca de Cáceres y a Francisco de Grimaldo aviéndola su alteza echado de la suya. A esto le dixe que yo pensaba que le avía hecho servicio en querer encobrir lo que no fuera onrra de su alteza que se publicara, y que yo no los avía recibido de nuevo en mi casa; que Francisco de Grimaldo tenía en mi casa dos cámaras alquiladas por sus dineros, como las tenían otros que posaban allí; que la casa era grande, y que el avía llevado su mujer a su aposentamiento; que era verdad que comía comigo el, porque desde que d'España vino siempre avía comido comigo, y su mujer comía con él algunas veces a mi mesa, y que sigún la vida que yo tenía en Inglaterra, a ellos o a otros avía de buscar que comiesen comigo, por no parecer del todo punto preso; mas que si su alteza me oviera mandado dezir que no era contenta dello, que yo no la enojara, mas que nunca nada me avía sido dicho ni por su alteza ni por otro de su parte; que no tenia razón de olvidar por esto los servicios que yo le avía hecho, ni era razón que me desonrrase como me desonrrava". 
negociaciones para llevar a cabo el matrimonio entre Catalina de Aragón y Enrique Tudor. En una carta sin datar a la infanta, pero que se puede fechar en diciembre de 1508, Gutierre Gómez de Fuensalida se muestra avergonzado por las exigencias del banquero ligur ante la princesa viuda de Gales, temiendo además la reacción del rey Fernando por este asunto ${ }^{66}$.

El desarrollo de los acontecimientos revela que Francesco Grimaldi y Francisca de Cáceres no se marcharon de Inglaterra. Aunque en marzo de 1509 el genovés seguía determinado a partir ${ }^{67}$, probablemente Fuensalida logró hacerle desistir de su propósito. El fallecimiento de Enrique VII en abril de 1509 habría facilitado también este hecho. Así pues, como se ha visto anteriormente, el banquero permaneció en la isla y tuvo un papel muy importante en el pago de la dote de la nueva reina de Inglaterra. Por otra parte, la carta de arras otorgada por Grimaldi a su mujer en Granada en octubre de 1510 revela que en el momento del matrimonio el genovés recibió 1.000 ducados en joyas y dinero de los 4.000 ducados prometidos por la reina en la real cédula que firmó ${ }^{68}$. Probablemente nunca recibió los 3.000 ducados restantes.

Comoquiera que fuera, parece claro que Francesco Grimaldi no tenía intención de regresar a la Corte, de donde había partido para ir a Inglaterra, sino que de vuelta a la

66 "A lo que Vuestra alteza dyze que no consyenta que Francisco de Grimaldo diga lo que dyze, ni haga amenaza que se quiere yr, no está en mano de nadie refrenar la lengua agena; y no crea Vuestra alteza que delante de mí el dirá cosa que no se deba dezir, porque sabe que aquello que estará en mi mano quisiera reprehendelle, que no a de cesar de hazerse; y por cierto yo no le e oydo dezir cosa que mala sea, salvo dezyrme a my que querrya que recibiese este dinero, porque él se pierde aquí, que no vino sino para estar un mes, y a estado diez comiendo de lo suyo cara quiete serene, y deseando hazer algún servicio a Vuestra alteza; y que pues pareze que este negocio se dilata, y que no es recebida su buena voluntad, quel se quiere yr, y que sy no quiero recebir el dinero, que me hará un requerimiento, y que con esto se yrá; lo qual yo le e bien rechazado, porque yo no tengo comisión para recebir el dinero, syno quando se ubiere de pagar, mandalle de partes del Rey, mi señor, que lo pague; en otra manera, ni él es obligado a dallo, ni yo lo puedo recebir; y esta yra su mujer y yo quanto avemos podido la avemos amansado; y deve Vuestra alteza considerar que éste no es súbdito del Rey, nuestro señor, y que su hazienda toda la puede llevar en dos dedos de papel, y más son de halagar los tales que de amenazallos; y no se yo lo que allá él dixo, ni lo que Vuestra alteza oyó; mas sy más fue de desear servir a Vuestra alteza, y ponello por obra quando el caso naciese, fue harta liviandad suya, y harta grandeza de Vuestra alteza dysimulallo; y sy yo supiese que él estaba de yntinción de executar lo que digo, que antenoche me dixo que se quería yr, no sería menester que Vuestra alteza se pusiese en trabajo para hazello saber al Rey, mi señor, que yo enbiaría correo volante, y le daría bien con que fuese, sin demandallo a Vuestra alteza, ni ponello en cuenta al Rey, mi señor, que por lo que toca a mi honrra y por salvarme de vergüenza lo avía de hazer quando yo lo supiese". Ibidem, pp. 554-555. La referencia de que el genovés lleva diez meses en Inglaterra (diciembre de 1508, habiendo llegado con Fuensalida a Londres el 22 de febrero de ese año) hace pensar que la estimación del duque de Alba, que fecha el documento en junio de 1509, es errónea. Confirmaría mi hipótesis la referencia a la dilatación de las negociaciones para celebrar la boda entre Catalina y Enrique. De hecho, a la luz de esta última información, la inclinación del duque de Alba por junio de 1509 no tiene sentido si se recuerda precisamente que el matrimonio tuvo lugar el día 11 de ese mes y año; y que el acuerdo sobre el pago de la dote se cerró el mismo mayo de 1509. Ver supra, nota 50.

67 "Todos sabían que Francisco de Grymaldo me avya requerydo que reçibiese el dinero, que se querya yr". Ibidem, p. 510, s.f., ?-III-1509.

68 "Al tienpo que con ella me desposé su alteza, por me haser merçed, me prometyó de dar en dote e casamiento con la dicha mi mujer quatro mill ducados de oro por una su çédula firmada de su real nonbre, e al dicho tienpo yo reçeby de la dicha doña Françisca, mi mujer, mill ducados en joyas de oro e en dinero e en otras cosas que lo valieron". En arras Grimaldi concedía a su mujer 2.000 ducados que había que unir a los 1.000 ducados recibidos en dote, en derechos sobre el cortijo del Bernel que poseía entre Moclín y Colomera, y sobre los 36.000 maravedíes que tenía de censo y tributo de las mancebías de Málaga, que había comprado a Hernán Núñez de Toledo. De la Obra Sierra, Mercaderes italianos, doc. 61, 16-X-1510. 
Península Ibérica quería retornar a Granada desde un principio. Así, lo indicarían dos cartas del mismo tenor escritas en abril de 1508 por Gutierre Gómez de Fuensalida a Agustín Italián y a Pedro López de Calatayud, que estaba en Brujas. En ellas decía referente a Francesco que "tiene ya rayzes en Granada y en Málaga, donde piensa biuir" $"$.

Las dificultades afrontadas en Inglaterra sacan a relucir un aspecto muy interesante sobre la identidad de Francesco Grimaldi. Avecindado en la ciudad cuando le encontramos por primera vez en Granada en 1496, se podría pensar que se había naturalizado castellano para tener más facilidades y acceso a las franquicias otorgadas al nuevo reino castellano tras su conquista, al igual que había hecho su primo Agustín Italián. A su llegada a Londres Grimaldi parecería insistir en su condición de súbdito ibérico. Es lo que cabría deducir de su deseo de servir no "como gynovés, mas como natural destos reynos y súbdito de vuestra alteza", según transmitía Fuensalida al rey Fernando $^{70}$. Sin embargo, ese mismo año, ante las quejas de la infanta Catalina sobre el proceder del banquero y la indicación de ésta al embajador de que moderara su comportamiento, Fuensalida le recordaba a la princesa que "deve vuestra alteza considerar que éste no es súbdito del Rey, nuestro señor, y que su hazienda toda la puede llevar en dos dedos de papel, y más son de halagar los tales que de amenazallos" No cabe duda de que el sentido de pertenencia a una nación -entendida en la acepción medieval del término- en el caso de estos extranjeros no era en esencia inamovible, sino que tenía un carácter mudable. Así lo reconocerían tanto los forasteros como los naturales, jugando con la identidad en función de los intereses de cada momento y actuando en consecuencia.

Gómez de Fuensalida debió abandonar Gran Bretaña a finales de verano o principios de otoño de 1509, según se deduce de su afirmación de que "tardé en el viaje diez e nueve meses e diez días" 72 . Al menos, es seguro que su sustituto, Luis Carroz, no partió de Burgos hasta noviembre de ese año. Sin embargo, resulta complicado saber en qué momento regresó Francesco Grimaldi a Granada. Sería tentador pensar que lo hizo acompañando al embajador con el que había llegado y que en breve se establecería como corregidor en la ciudad de la Alhambra. En todo caso, como se verá inmediatamente, los protocolos notariales granadinos atestiguan su presencia en la ciudad unos meses más tarde, durante el verano de 1510, pero todo parece indicar que no volvió acompañado de su mujer. Efectivamente, en mayo de 1510 Luis Carroz escribía al secretario real Miguel Pérez de Almazán dando cuenta de la presencia en Londres de Francisca de Cáceres, aunque fuera de la Corte desde que perdió el favor de la reina Catalina. Sin nadie que le informara de lo que ocurría dentro de palacio, Carroz buscaba el apoyo de Almazán para lograr colocar a Francisca de Cáceres en el séquito de la princesa María Tudor, hermana de Enrique VIII ${ }^{73}$.

${ }^{69}$ Correspondencia, p. 444, 27-IX-1508.

70 Ibidem.

71 Ibidem, p. 555, ?-XII-1508.

72 Ibidem, p. 591.

73 “Aquí esta aquella criada de la Reyna que se dize Francisca de Cáceres y casó con Francisco Grimaldo. Es la más aficionada persona al servicio de Su Alteza del mundo y la mas ábil para lo que conviene assí a la Reyna como al Rey nuestro Señor. Témela el frayle cosa que no se puede dezir, y éste nos defiende que ésta ni entra en palacio ni para estar en servicio de la Reyna ni para verla. Ternía yo por bien dos cartas de su alteza, 
Sin embargo, Francisca de Cáceres no logró regresar a la Corte inglesa, a pesar de que incluso Margarita de Austria intercedió en su favor ante su cuñada, la reina Catalina, para que volviera a tomarla a su servicio ${ }^{74}$. Más aún, la soberana se habría negado a recomendarla en modo alguno, aduciendo que era una mujer peligrosa ${ }^{75}$. En este sentido, parece que el juicio de la reina no era del todo equivocado, pues el nombre de su antigua camarera salió a relucir en el escándalo que afectó a Anne Stafford en mayo de $1510^{76}$.

Sin embargo, el rey Fernando le demostró una consideración muy superior a la de su hija, reconociendo la utilidad de sus servicios. Es lo que expresa claramente tres años más tarde, cuando Francisca de Cáceres continuaba intentando regresar a la Corte inglesa. Efectivamente, en julio de 1513 el monarca aragonés firmaba unas instrucciones para que Diego de Quirós se las hiciera llegar al embajador Carroz, y en ellas aprobaba que la antigua camarera de su hija Catalina entrara al servicio de María Tudor, hermana de Enrique VIII en esos momentos prometida a Carlos de Gante, duque de Borgoña y príncipe de Asturias. Para ello, como en el pasado, recurría a su nuera, Margarita de Austria, que también habría mostrado su estima por la dama castellana ${ }^{77}$.

En este punto la información se vuelve confusa. Precisamente al tiempo que Fernando de Aragón recomendaba el servicio de nuestra dama, Catalina solicitaba ayuda nada menos que al poderoso cardenal Thomas Wolsey, el consejero y administrador de Enrique VIII aspirante al cargo de Lord Canciller, para conseguir deshacerse de Francisca, a la que finalmente no habría quedado más remedio que regresar a la Península Ibérica ${ }^{78}$. Sin embargo, el 8 de diciembre de 1513 Fernando el Católico escribía dos cartas idénticas a Pedro de Urrea, embajador en Flandes, donde actuaba como regente Margarita de Austria, y a Luis Carroz, embajador en Londres según se ha visto, en las que de nuevo daba su beneplácito para colocar a Francisca junto a

la una para el Rey, la otra para la Reyna, de ruego y en fin con crehencia para mí y lo que yo entiendo de fazer es probar si se podrá acabar que la Reyna la cobre en su servicio y donde no fazer que el Rey la tome para madama María su hermana, y pues esté dentro en palacio ella misma se cobrara el lugar y sin cobrarle allá aprovechara muy mucho que agora no teniendo allá nadie no alcanço lo de allá como sería menester”. AGS, PR, Capitulaciones y Tratados con Inglaterra, leg. 5, s.f., 29-V-1510. Cifrado. Publicado "Queen Katharine: 1510", pp. 34-44.

74 Mattingly, Catalina de Aragón, p. 179.

75 Tremlet, Catherine of Aragon, p. 155.

${ }^{76}$ Luis Carroz, fuente principal del escándalo, habría sido informado por Francisca de Cáceres del rumor cortesano que señalaba que la hermana del duque de Buckingham estaba siendo cortejada por el fogoso Enrique VIII en un momento de crisis conyugal con Catalina de Aragón. Mattingly, Catalina de Aragón, pp. 179-180.

77 "En lo de Francisca de Cáceres le diréys que me ha parecido muy bien que él y los otros mis embaxadores hayan procurado que sea assentada y recebida en seruicio de la ilustrisima princessa de Castilla madama María mi fija porque según la relación que tengo de la virtud y la abilidad de la dicha Francisca de Cáceres y de la afection que tiene a nuestro real estado y seruicio tengo por cierto que seruirá muy bien y embio con la presente carta mía para la yllustrísima madama Margarita mi fija, por la qual le ruego que la quiera recebir y poner en servicio de la dicha yllustrísima princesa de Castilla mi fija y escriuo a mossen Juan de la Nuça mi embaxador que procure negociar i acabar con ella". AGS, Patronato Real, leg. 54, fol. 109, 6-VII-1513. Publicado en Doussinague, Fernando el Católico, p. 632.

78 WeIr, The Six Wives, pp. 99-100. 
la princesa María ${ }^{79}$. En cualquier caso, la ruptura del compromiso matrimonial con Carlos de Gante y la boda de María Tudor al año siguiente con Luis XII de Francia habría dado al traste con las aspiraciones de Francisca y del rey Fernando de hacerla regresar a la Corte al servicio de la princesa inglesa. Así pues, parece claro que Francisca de Cáceres habría regresado a la Península Ibérica, a más tardar, en la primera mitad de $1514^{80}$.

\section{5. ÚLTIMA ESTANCIA EN GRANADA (1510-1519/20): EL PATRIMONIO DE FRANCESCO GRIMALDI}

En consecuencia, parece probable que Francesco Grimaldi regresara a Granada sin su mujer, aunque es de todo punto imposible saber si los hijos habidos en el matrimonio viajaron con su padre o si, por el contrario, permanecieron en Inglaterra con su madre ${ }^{81}$.

Probablemente no sea casualidad que el nombre del banquero genovés comparezca de nuevo en los protocolos notariales de Granada precisamente a partir de 1510. En enero de ese año recibía una real cédula en la que la Corona le hacía donación de 20.000 maravedíes en bienes raíces en el Reino de Granada. Y entre enero y febrero escrituraba diversas propiedades en las Alpujarras, en Berja y Murtas ${ }^{82}$. Además, en marzo de ese año el mercader genovés Juan de Gra, a quien habíamos visto actuando junto con Grimaldi en Málaga en 1497, ejercía como administrador del cortijo del Berbe, entre las villas de Moclín y Colomera, cobrando diversas deudas en su nombre. Así, tan pronto prestaba en marzo 40 fanegas de cebada al saludador Alonso Millán, vecino de Colomera, como hacía lo mismo con 10 fanegas de trigo al hortelano Juan de Palenzuela, vecino de Santa Fe ${ }^{83}$.

79 "También travajad que con la Princesa de Castilla Madama María se pongan algunas personas y la pongan y conserven en nuestro amor y obediencia. Y por una paréceme vien Francisca de Cáceres". AGS, Estado, Alemania, leg. 635, fol. 10, 8-XII-1513; AGS, Estado, leg. 806, fol. 13, 8-XII-1513. Publicado en Doussinague, Fernando el Católico, apéndices 148 y 151.

${ }^{80}$ Otro dato más apunta en este sentido. El Memorial de la familia ya aludido refiere que a Juan Grimaldo y Cáceres "le sacó de pila el cardenal Julio que después fue sumo pontífice y se dijo papa Clemente séptimo". Probablemente el dato sea falso, pues si bien es cierto que Giulio de' Medici fue Cardenal Protector de Inglaterra de 1514 a 1523, no lo es menos que no se desplazó a la isla y ejerció su función fundamentalmente desde Roma. Pero, habiendo aceptado oficialmente el nombramiento en febrero de 1514 sí podría indicar que Francisca de Cáceres aún se encontraba en territorio inglés en la primera mitad de ese año. El Memorial en RAH, 9/317, fols. 86r-87r; las negociaciones para el nombramiento del cardenal Medici y su aceptación en WILKIE, The Cardinals Protectors, pp. 81-83.

81 En octubre de 1510 Francesco Grimaldi otorgaba carta de arras "a la dicha doña Françisca de Cáceres, mi mujer, por honrra de su persona e linaje, e de los hijos e hijas que en uno avemos avido". DE LA OBRA SiERrA, Mercaderes italianos, doc. 61, 16-X-1510.

${ }^{82}$ También adquirió propiedades en Ugíjar, pues en 1520 estaba vendiéndolas a Juan de Alcocer. Toda la información en ADG, L 07872.

83 De la Obra Sierra, Mercaderes italianos, docs. 17 (2-III-1510) y 21 (8-IV-1510). El cortijo debió adquirirlo por el impago de la deuda de 247.000 maravedíes que el tesorero Ruy López de Toledo tenía con él en 1506, y que se comprometió a entregarle si en el plazo de dos años no le devolvía la cantidad. Ver supra nota 32 . 
Ocasionalmente Juan de Gra también realizaba operaciones mercantiles sin su cuñado. Así, en mayo de 1510 figuraba como vecino de Málaga, cuando Benito Cavalli, mercader genovés vecino de Granada, acordaba que debía pagarle a él y a Esteban Ricio, mercader estante en el puerto malagueño, 15.360 maravedíes por 8 balas de papel que le había comprado, del que Marcos Squarzafico había descargado en la ciudad. Y en septiembre de ese año los tres, Grimaldi, Gra y Squarzafico, vendían 300 puercos "grandes e pequeños", una borrica "ruçia con una criança", tres perros, una caldera, dos costales y una manta a Pascual Sánchez de Orgás y Mendo de Valdés, vecinos de Granada avalados por el clérigo Francisco de Valdés, hermano del segundo, por 70.000 maravedíes $^{84}$.

Es seguro que en el verano de 1510 Francesco Grimaldi estaba en Granada. A finales de agosto actuaba como testigo en el poder que los hermanos Agustín y Juan Bautista Lomelin, mercaderes genoveses estantes en Granada, otorgaban a Gregorio Catano, asimismo ligur estante en la ciudad, para que cobrara "todos los maravedís e mercaderías e lanas" que les debían en la ciudad ${ }^{85}$. Y a principios de otoño ya aparece actuando en persona. Así, en septiembre de 1510 arrendaba a los moriscos Francisco Fernández Abucequén, alguacil y vecino de la alquería de Víznar; a Jaime Xarrili, Francisco de Abdonzas, Francisco Xafea y Francisco Alhadil, vecinos de la misma alquería, todas las tierras de pan llevar que le pertenecían en el cortijo del Berbe por tiempo de 5 años $^{86}$. Por su parte, Grimaldi salía como fiador de Abucequen y Alhadid, asegurando que ambos, en su cometido de vigilar su hacienda, no dañarían las posesiones de sus vecinos ${ }^{87}$.

Además, en octubre tomaba a soldada a Pedro Abucequen durante un año para que trabajara en un majuelo del cortijo, pagándole 6.000 maravedíes, y entregaba a Francisco Fernández Abucequen y Jaime Xarrili todos los barbechos del cortijo para que los sembraran ese mismo año, dejándoles a sus criados para que les ayudaran, a cambio de que le entregaran la mitad de la cosecha ${ }^{88}$. Todavía tendría más tratos con moriscos: en enero de 1512 Leonor Mohalala, viuda de Pedro Aben Catalon, vecinos de Granada y anteriormente de Berja, vendía a Lorenzo el Muede unas casas situadas en la localidad almeriense, una huerta y un tercio de molino de pan moles sito al pie de la huerta. Los otros dos tercios pertenecían precisamente a Francesco Grimaldi ${ }^{89}$.

${ }^{84}$ Ibidem, doc. 31, 11-V-1510; 49, 9-IX-1510. Dos meses más tarde Francisco Valdés, en nombre de Mendo Valdés y de Pascual Sánchez, vendería los animales en nombre de Grimaldi por la misma cantidad a Antón García de Alcántara, a su hijo y a su yerno, vecinos todos de Santa Fe. Ibidem, doc. 64, 10-XI-1510.

${ }^{85}$ Ibidem, doc. 45, 31-VIII-1510.

${ }^{86}$ Como renta recibiría 5 fanegas de lo que recogieran cada año, y 1 fanega de todo el trigo, cebada y cualquier ora semilla que sembraran, estando obligados a sembrar la mitad de las tierras del cortijo cada año, a rozar y limpiar todo lo que pudieran de las tierras que no fueran monte cerrado; y a pagar 2 gallinas cada uno, hasta un total de 12 gallinas castellanas. Todo con la condición además de que pudieran criar y tener en el cortijo todo el ganado y las aves que quisieran; la paja que tenía en el pajar del cortijo se la arrendaba también. Por su parte, Grimaldo se obligaba a darles diez casas "con sus puertas de retama" dentro del cortijo, y que le debían dejar bien techadas. Además, por cada fanega de tierra que dejaran de sembrar de la mitad del cortijo, estarían obligados a pagarle dos fanegas de pan. Y si las casas se las daban techadas con teja debían devolverlas tal cual las recibían. Ibidem, doc. 50, 23-IX-1510.

${ }^{87}$ Ibidem, doc. 53, 26-IX-1510.

88 Ibidem, docs. 56 y 57, 6-X-1510.

89 Regestado por dE la Obra SiERra, Catálogo, regesta 2049, 5-I-1512. 
En noviembre y diciembre es el ganado el que centra sus operaciones. Así, vendía dos yeguas con sus crías a los hermanos Francisco y Cristóbal de Pernia, vecinos de Granada, por 5.000 maravedíes; y arrendaba al saludador Alonso Millán y a Alonso Lorenzo, vecinos de Colomera, tres bueyes (dos de color hosco y uno rubio) y dos bueyes respectivamente, por tres y dos cahíces de trigo a cada uno, hasta mayo del año siguiente ${ }^{90}$.

A partir de 1511 las referencias documentales a Francesco Grimaldi se hacen cada vez más escasas. Efectivamente, en marzo de ese año Cristóbal de Villafranca, alcaide de la villa de Freila, regidor y vecino de Baza, apoderaba al granadino Antón de Jaén para que demandara a Francesco Grimaldi los 10.000 maravedíes que Agustín Italián le había librado en su primo ${ }^{91}$.

$\mathrm{Al}$ año siguiente Juan de Gra volvía a actuar en nombre de su cuñado, lo que tal vez sea indicativo de que de nuevo se había ausentado de Granada. En febrero de 1512 cobraba de Francisco de Toledo, vecino de la ciudad, como fiador de Hernando de Marchena, la deuda que este último tenía con Grimaldi de 10.000 maravedíes, más otros 400 maravedíes de $\operatorname{costas}^{92}$. En noviembre de ese año estaba sustituyendo el poder que tenía de su cuñado en Agustín de Vivaldo, Damián de Fiesco y Francisco Marin, mercaderes genoveses estantes en la Corte, así como en Pedro Hernández de Córdoba, vecino de Sevilla, para que notificaran a Francisco Romero ciertas escrituras y requerimientos y los hicieran cumplir para salvaguarda del derecho de Francesco Grimaldi ${ }^{93}$. Por último, en diciembre el morisco Diego Calderón Moxarral, vecino de Ugíjar, debía pagar a Grimaldi 7.000 maravedíes que él y Francisco de Cuevas le debían de la renta de ciertos bienes que le habían arrendado en Berja.

Al final de su vida aparecen de nuevo nombres de etapas pasadas. Efectivamente, Francisco Romero había arrendado las mancebías de Málaga de 1505 a 1510 y había pleiteado con Fernán Núñez de Toledo cuando éste tenía una deuda con Grimaldi a propósito precisamente de la renta de las mancebías malagueñas ${ }^{94}$. Por su parte, Francisco Marin era uno de los arrendadores de la renta de la Alpujarra que en 1500 reclamaba a Grimaldi y Peñalver que cumplieran el arbitraje sobre el arrendamiento de 1496 y $1497^{95}$. Por último, Agustín de Vivaldo realizó un préstamo in solidum junto con Grimaldi y Nicolas Lomellino en 1509 a Fernando el Católico para poder pagar la dote de la infanta Catalina ${ }^{96}$.

En 1513 hay una única referencia a Francesco Grimaldi, procedente de una ejecutoria de un pleito conservado en la Chancillería de Valladolid, litigado en marzo

${ }^{90}$ De la Obra Sierra, Mercaderes italianos, docs. 67 (14-XI-1510), 71 (24-XI-1510) y 76 (12-XII$1510)$

${ }_{91}$ Crespo Muñoz, El notariado en Baza, doc. 157 (141), 9-III-1511.

92 De la Obra Sierra, Mercaderes italianos, doc. 102, 13-II-1512. La deuda se cobró en parte sobre la ejecución de algunos bienes; además Francisco de Toledo salió por fiador de seguimiento a Sebastián de Rojas, vecino de Granada, y se cobraron de la siguiente manera: 6.372'5 maravedíes de Marco Squarzafico; 2.086 '5 de Sebastián de Rojas, recibiendo la mitad Gregorio Catanno en nombre de Grimaldi; el resto (1.541 mrs) los recibió Juan de Gra en un cambio de Pedro de Andújar en nombre de Sebastián de Rojas.

${ }^{93}$ Ibidem, docs. 115 (20-XI-1512) y 118 (30-XII-1512).

${ }^{94}$ Ver supra, nota 14.

${ }_{95}$ Ver supra, nota 19.

${ }^{96}$ Ver supra, nota 50. 
de ese año contra Pedro Báez, vecino de Medina del Campo, sobre el pago de unas deudas ${ }^{97}$.

Después del fallecimiento del rey Fernando en enero de 1516 Grimaldi adquirió nuevas propiedades en las Alpujarras granadinas. Así, aunque el Memorial familiar ya citado está plagado de falsedades, probablemente sea cierto que

el emperador hizo merced de dos lugarejos a Francisco de Grimaldo mi señor en la Alpujarras, y ya había antes hecho merced de ellos el rey católico a un caballero Zapata y en el pleito sobre cual merced había de valer y aun dicen que de enojo murió Francisco de Grimaldo mi señor en el camino de las Alpujarras yéndose a meter en ellos ${ }^{98}$.

Es posible que se trate de enclaves en el señorío del Zehel, mayorazgo de los Zapata ${ }^{99}$.

Las últimas noticias proceden del verano de 1519, cuando compró al duque Adolfo de Cleves un batán en las Alpujarras ${ }^{100}$. Un año más tarde ya había fallecido, pues en noviembre de 1520 su viuda y sus hijos tomaban posesión de unas casas principales en la colación de San José, a espaldas de su capilla mayor, ejecutadas por la deuda contraída por Pedro Peñalver con Grimaldi ${ }^{101}$.

\section{LA FAMILIA GRIMALDO DE CÁCERES (GRANADA, PRIMERA MITAD DEL SIGLO XVI)}

Como se ha visto, es muy poco lo que se sabe sobre la familia de origen de Francesco Grimaldi. Se ha podido documentar su parentesco con los hermanos Italián, sus primos Agustín, Pantaleón y Gaspar, pero no se han podido confirmar las informaciones que apuntaban a otro primo más en Londres, Giovanni Battista Grimaldi. De hecho, por el momento es imposible establecer si tenía algún grado de parentesco con los Grimaldi establecidos en la Corona de Castilla, en Sevilla y en la Corte. Por otra parte, Francesco debía tener al menos una hermana, cuyo nombre se ignora, que casó en fecha indeterminada con Juan de Gra, quien aparece como su cuñado mientras actuaba en su nombre en 1510 .

Las informaciones sobre su mujer, Francisca de Cáceres, son más prolijas en lo que se refiere a su estancia en la Corte inglesa junto a Catalina de Aragón y las inusuales circunstancias del matrimonio de ambos, pero no sobre su filiación, ni sobre la rea-

${ }^{97}$ Efectivamente, el genovés Francisco de Marin, en nombre de Francesco Grimaldi, solicitaba al teniente de corregidor de Medina del Campo la entrega de la persona y bienes de Pedro Báez, vecino de dicha villa, por una obligación de 25.300 maravedíes, resto de una deuda mayor que tenía con Grimaldi, a lo que el oficial municipal accedió. Archivo de la Real Chancillería de Valladolid, registro de ejecutorias, caja 284, 28, 12-IV1513.

${ }^{98}$ RAH, 9/317, fols. 86r-87r.

99 GARCía SÁNCheZ, "La constitución".

100 ADG, L07872, 23-VII-1519 y 19-VIII-1519. Agradezco el dato al colega y amigo Rafael Girón Pascual. Efectivamente, en mayo de 1519 Adolfo de Cleves recibió por donación real los bienes habices usurpados en Granada desde 1506. Padilla Mellado, "El Duque de Cleves", pp. 349-378.

${ }^{101}$ Un mes más tarde las vendían a Fernando Díaz. Información procedente del Inventario de documentos procedentes del mayorazgo de doña Francisca de Cáceres (1736), ADG, L07872. 
lidad familiar de la pareja después del matrimonio de la infanta española y Enrique VIII de Inglaterra. De la unión se han podido documentar dos hijos, Juan Grimaldo y Cáceres y Leonor de Cáceres. Es prácticamente seguro que el primero nació en Inglaterra hacia 1513, lo que implicaría que Grimaldi regresó a Gran Bretaña antes de la marcha de su mujer en algún momento ${ }^{102}$.

Las actividades de Francisca de Cáceres como viuda son de dos décadas posteriores al fallecimiento de Francesco Grimaldi. Efectivamente, en marzo de 1539 había fundado ante Juan de Sosa un mayorazgo entre cuyos bienes se contaban unas casas en Granada; el cortijo del Berbe, con tierras, casas y viñas que en el XVIII tenían 3.560 fanegas de tierras de labor, monte, rozas etc; 200 ducados de censo anuales redimibles por 2.000 ducados que pagó Pedro Ruiz de la Sima; y censos perpetuos en la Alpujarra y Berja por 20.000 maravedíes anuales para la fundación de una capellanía ${ }^{103}$. Entre las cláusulas fundacionales del mayorazgo dispuso que, a falta de herederos, la hacienda fuera a parar al hospital de San Juan de Dios ${ }^{104}$.

Las propiedades en Berja las confirma el Libro de Apeo de la localidad, que las señala en las lindes de algunas fincas del repartimiento ${ }^{105}$. Además, son varios los documentos que testimonian la fundación de una capellanía servidera en el Real Monasterio de los Jerónimos de Granada dotada con 20.928 maravedíes, donde sería enterrada ${ }^{106}$.

En 1542 doña Francisca de Cáceres seguía viva, plenamente integrada en los círculos sociales de poder de la ciudad y dedicada a obras de caridad. Es lo que se desprende de una declaración del presbítero Rodrigo Alonso de Eseguera, camarero del arzobispo de Granada, en torno a la actuación de San Juan de Dios en la ciudad:

El dicho Juan de Dios y el dicho maestro Juan de Ávila, el licenciado Ríos e otros caballeros e veinte e cuatros de esta ciudad andaban por las calles e casas de esta ciudad e doña Francisca de Cáceres, madre del comendador Juan de Grimaldo por otra parte, todos andaban con platos de plata pidiendo limosnas para labrar un cuarto en el dicho sitio donde se pudiesen recoger los enfermos, porque estaban sin abrigo. Y esto sabe: que todos daban e se allegó cantidad de reales, con que se comenzó a edificar un cuarto en el dicho sitio ${ }^{107}$.

\footnotetext{
102 Ver supra nota 80.
}

103 ADG, 5536-1 y 5536-2. De nuevo, debo los datos sobre la fundación y los bienes del mayorazgo a la generosidad del colega y amigo Rafael Girón Pascual.

104 Ciudad Gómez-Bueno, Historia de la Orden, p. 56, afirma que el Hospital tomó posesión de los bienes en 1556 porque Francisca de Cáceres falleció sin herederos. Evidentemente, se trata de un dato erróneo. El mayorazgo continuó en la familia hasta el fallecimiento de don Gaspar Girón Venegas de Córdoba Grimaldo, caballero de Santiago y aposentador mayor de Carlos II de Austria y Felipe V de Borbón, con cuyo fallecimiento se extinguieron los descendientes masculinos de la familia, ya en el siglo XVIII. Cf. GIRÓN PASCUAL, Las Indias de Génova, p. 218.

105 Archivo Municipal de Berja, Libro de Apeo y Repartimiento de Berja y Adra, fol. 124r. Citado por SÁnchez RAmos, "La colonia genovesa”, p. 188.

106 ARChG, 201-5135-11, piezas 5 y 6. Tomado de SÁnchez Ramos, "La colonia genovesa”, p. 186. MARín LóPEZ, “Origen y evolución”, p. 241.

107 SÁnchez Martínez, 'Kénosis-Diakonía', pp. 400-401. 
Lo ratifica asimismo la declaración que hizo su hija, doña Leonor de Cáceres, en 1572, a propósito de las circunstancias que envolvieron la construcción del Hospital San Juan de Dios de Granada. Efectivamente, según decía Leonor, Francisca hizo construir un cuarto porque no cabían los pobres en el edificio que se empleaba, pero la prisa con la que se edificó y las lluvias abundantes de ese año provocaron su derrumbe, provocándole gran pesar "porque ella lo labraba de las limosnas que todos davan". Unos días más tarde, después del incidente, fray Diego de Linares, prior de los jerónimos, acudió a la Alhambra a felicitar la Navidad al don Luis Hurtado de Mendoza, II marqués de Mondéjar y capitán general de Granada, y "el marqués dixo a fray Diego que entrase a consolar a doña Francisca, que estava muy triste". En el palacio fray Diego expuso a doña Francisca cómo continuar con la obra. En el transcurso de la conversación ésta se comprometió a que si las limosnas no bastaban "ella los daría de su hazienda, e se obligaría a ello porque la buena obra no se dexase de hazer". Más adelante doña Francisca y su hija fueron "convidadas para ver hacer los cimientos del ospital y poner las primeras piedras" 108 .

Así pues, no cabe ninguna duda de que doña Francisca, una vez fallecido su marido, supo establecer relaciones en Granada al más alto nivel, valiéndose de la experiencia adquirida en la Corte inglesa. Mantuvo el patrimonio de su marido y logró que sus hijos ascendieran en la escala social, integrándose plenamente con familias con abolengo de la nobleza castellana. Efectivamente, su hija, Leonor de Cáceres, se casó con Rodrigo Ponce de León Ocampo. Por su parte su hijo, Juan Grimaldo y Cáceres, ingresó en la Orden de Santiago en 1539 ${ }^{109}$, donde alcanzó el grado de comendador, y participó en diversas batallas navales como el Gran Sitio de Malta (1565) o Lepanto $(1571)^{110}$. Contrajo nupcias con doña Juana de Zúñiga Avellaneda Mendoza. Ambos tuvieron descendencia ${ }^{111}$.

\section{CONSIDERACIONES FINALES}

La vida y la trayectoria de Francesco Grimaldi presenta elementos comunes a las de otros miembros de la comunidad mercantil genovesa presente en la Corona de Castilla durante el reinado de los Reyes Católicos, pero también ofrece algunos rasgos diferenciales que lo perfilan como una figura altamente singular. Destaca en primer lugar su predilección por las operaciones financieras sobre las mercantiles. En este sentido, su interés por la renta sobre las mancebías de Málaga o la renta de la Alpujarra ofrece nuevos datos sobre la participación extranjera en la recaudación de rentas castellanas en el Reino de Granada, un aspecto sobre el que habrá que seguir profundizando en el futuro.

$\mathrm{Su}$ estancia en la Corte anuncia el protagonismo que los grandes banqueros genoveses tendrán en la Monarquía Hispánica del siglo XVI. Asociado con su primo Agustín Italián, desempeñó un papel fundamental en el pago de la dote de la infanta

\footnotetext{
108 SÁnchez Martínez, “Granada”, pp. 385-386, 389.

109 Girón Pascual, Las Indias, p. 254.

110 Lambert-Gorges, "Santiago", p. 244.

111 Puede verse el cuadro genealógico elaborado por Girón Pascual, Las Indias, p. 402.
} 
Catalina, tanto para el matrimonio con el príncipe Arturo de Gales como, tras su fallecimiento, con su hermano, el futuro Enrique VIII de Inglaterra. El desplazamiento a la Corte inglesa con Gutierre Gómez de Fuensalida ha dejado un rastro documental de excepcional riqueza sobre su participación en el desarrollo de los acontecimientos como mano derecha del embajador y en lo referente a su matrimonio con Francisca de Cáceres, camarera de la infanta.

El matrimonio con una miembro de la nobleza castellana era más habitual en Andalucía de lo que lo fue en el Reino de Granada tras la conquista castellana ${ }^{112}$. Sin embargo, no es menos cierto que en el caso concreto de Francesco Grimaldi concurrieron circunstancias absolutamente excepcionales, pues el enlace vino condicionado por la difícil situación de Catalina de Aragón en la Corte inglesa y a la postre fue una jugada más de la lucha de poder que mantenían el confesor de la princesa y el embajador Fuensalida.

A su regreso a Granada se hizo con un importante patrimonio inmobiliario, que sirvió de base para la carta de arras concedida a su mujer, y que ésta emplearía más adelante para fundar un mayorazgo que continuó hasta el siglo XVIII. Por otra parte, a pesar de que parece claro que Francesco Grimaldi no se naturalizó, su fallecimiento hizo que sus hijos se criaran plenamente integrados en la sociedad castellana, sirviéndose de los mecanismos habituales de promoción social gracias a los contactos establecidos por su madre, Francisca de Cáceres, después de quedar viuda.

\section{BIBLIOGRAFÍA}

Alonso García, David, El erario del reino. Fiscalidad en Castilla a comienzos de la Edad Moderna (1504-1525), Valladolid: Junta de Castilla y León, 2007.

Alonso García, David, "Una nación, diferentes familias, múltiples redes. Genoveses en Castilla a principios de la Edad Moderna", en Ana Crespo Solana (coord.), Comunidades transnacionales. Colonias de mercaderes extranjeros en el Mundo Atlántico (1500-1830), Madrid: Doce Calles, 2010, pp. 65-82.

Bratchel, M. E., "Italian Merchant Organization and Business Relationships in Early Tudor London", The Journal of European Economic History, 7/1 (1978), pp. 5-32.

Carretero Zamora, Juan Manuel, "Los servicios de Cortes y las necesidades financieras de la monarquía castellana (1500-1515)", Cuadernos de Historia Moderna y Contemporánea, 8 (1987), pp. 31-56.

Ciudad Gómez-Bueno, Juan, Historia de la Orden Hospitalaria de San Juan de Dios, Granada: Archivo Interprovincial, Casa del Tránsito de San Juan de Dios, 1963 [edición revisada de 2012].

Crespo Muñoz, Francisco J., El notariado en Baza (Granada) a comienzos de la Edad Moderna. Estudio y catálogo de los protocolos notariales (1510-1519), Granada, Tesis Doctoral: Universidad de Granada, 2007.

\footnotetext{
112 Así lo han puesto de manifiesto diversos estudios de SÁNCHEZ-SAus, Linajes sevillanos; "La aristocracia gaditana"; Linajes medievales. Emparentar con la nobleza castellana era una estrategia de movilidad social empleada por los genoveses establecidos en Andalucía desde el siglo XIII. Cf. GonZÁLEz ArÉvalo, "Integración y movilidad".
} 
Crónica del Rey Enrico Otavo de Inglaterra, edición, introducción y notas del Marqués de Molins, Madrid: Librería de los Bibliófilos, 1874.

D'ArIEnzo, Luisa, La presenza degli italiani in Portogallo al tempo di Colombo, Roma: Istituto Poligrafico e Zecca dello Stato, 2004.

De la Obra Sierra, Juan M. , Catálogo de Protocolos Notariales. Granada (1505-1515), Granada, Tesis Doctoral: Universidad de Granada (microfichas digitalizadas), 1986.

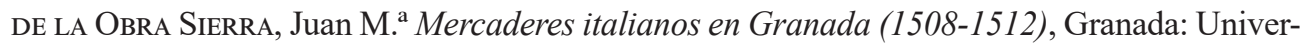
sidad de Granada, 1993.

DíAZ DE LA GUARDia y LóPEZ, Luis, "La guerra de las comunidades en la ciudad de Jaén. Y la responsabilidad civil derivada del delito exigida por Cristóbal de Biedma y Juan de Santoyo, Leales al Rey-Emperador", Espacio, Tiempo y Forma, serie IV, H. Moderna, 16 (2003), pp. 53-151.

Doussinague, José M. ${ }^{a}$, La política internacional de Fernando el Católico, Madrid: EspasaCalpe, 1944.

Doussinague, José M. ${ }^{a}$, Fernando el Católico y el Cisma de Pisa, Madrid: Espasa-Calpe, 1946.

Duque de Berwick y De Alba [Jacobo Fitz-James Stuart y Falcó] (ed.), Correspondencia de Gutierre Gómez de Fuensalida. Embajador en Alemania, Flandes e Inglaterra (1496-1509), Madrid: s.e., 1907.

FÁBregas García, Adela, Un mercader genovés en el reino de Granada. El libro de cuentas de Agostino Spinola (1441-1447), Granada: Universidad de Granada, 2002.

FÁBregas GARCÍA, Adela, La familia Spinola en el reino nazari de Granada. Contabilidad privada de Francesco Spinola (1451-1457), Granada: Alhulia, 2004.

FERnÁNDEZ DE NAVARRETE, Martín, Colección de los viages y descubrimientos que hicieron por mar los españoles desde fines del siglo $X V$, con varios documentos inéditos concernientes à la historia de la marina castellana y de los establecimientos españoles en Indias. Tomo I. Viages de Colón: Almirantazgo de Castilla, Madrid: Imprenta Real, 1825.

Fernández de NaVARrete, Martín (ed.), Colección de Documentos Inéditos para la Historia de España (CODOIN), 1, Madrid: Imprenta de la viuda de Calero, 1842.

Ferrer i Mallol, M. a Teresa, "Els Italians a terres catalanes", Anuario de Estudios Medievales, 10 (1980), pp. 393-467.

GARcía GÁMEz, Felix, "La renta de la seda del Reino de Granada y sus arrendadores en el Marquesado de los Vélez en época mudéjar (1490-1504)", en Francisco Andújar Castillo y Julián Pablo Díaz López (coords.), Los señorios en la Andalucía Moderna. El Marquesado de los Vélez, Almería: Instituto de Estudios Almerienses, 2007.

GARCÍA SÁNCHEZ, Antonio J., "La constitución del señorío de Çehel en las Alpujarras. Formación de un señorío tras la conquista de Granada en 1492", Andalucía en la Historia 40, Abril 2013, pp. 40-43.

García Valverde, M. ${ }^{a}$ Luisa, Moreno Trujillo, M. ${ }^{a}$ Amparo y de la Obra Sierra, Juan M. ${ }^{\mathrm{a}}, \mathrm{Di}$ plomatario del Reino de Granada. Documentos procedentes de la sección Registro General del Sello del Archivo General de Simancas, año de 1502, Granada: EUG, 2010.

Garrido Raya, Enrique y Moreno Escalante, Valentín, "La red mercantil de los Grimaldi y su proyección desde Sevilla a La Española (1489-1497)”, Temas Americanistas, 29 (2012), pp. 7-20.

GIRón Pascual, Rafael, Las Indias de Génova. Mercaderes genoveses en el Reino de Granada durante la Edad Moderna, Granada, Tesis Doctoral: Universidad de Granada, 2012. 
Girón Pascual, Rafael, "Francisca de Cáceres: A lady-spy in Catherine of Aragon's court", presentado en el Congreso Internacional Anglo-Iberian Relations, 1500-1850, Mértola, Portugal, 9-11 de abril de 2015, en prensa.

GonzÁLez ArÉvalo, Raúl, "Presencia diferencial italiana en el sur de la Península Ibérica en la Baja Edad Media. Estado de la cuestión y propuestas de investigación", Medievalismo, 23 (2013), pp. 175-208.

GONZÁLEZ ArÉvAlo, Raúl, "Exilio, diversificación, superación. Estrategias de supervivencia de los Spinola de Granada ante la guerra final de conquista (1481-1492)", Reti Medievali Rivista, 14/2 (2013), pp. 89-110, [en línea], disponible en: http:/www.rmojs.unina.it/index.php/ $\mathrm{rm} /$ article/view/403, [última consulta 25/02/2015].

GonZÁLEZ ArÉVAlo, Raúl, “De las postrimerías nazaríes a los albores castellanos. Ambrogio Spinola y la continuidad de los genoveses del Reino de Granada (1478-1508)", Archivio Storico Italiano, 644 (2015), pp. 239-273.

GonZÁlez ArÉvalo, Raúl, "Integración y movilidad social de las naciones italianas en la Corona de Castilla: genoveses, florentinos y venecianos en la Andalucía bajomedieval", en Lorenzo Tanzini y Sergio Tognetti (eds.), Mobilità sociale e forme di integrazione nel tardo Medioevo, Roma, Viella, 2016, en prensa.

IGUAL LuIs, David, Valencia e Italia en el siglo XV. Rutas, mercados y hombres de negocios en el espacio económico del Mediterráneo occidental, Castellón: Bancaixa, 1998.

LAmbert-Gorges, Martine, "Santiago et la défense de la Méditerranée (Notes sur le XVIe siècle)", en Las Órdenes Militares en el Mediterráneo occidental, Madrid: Casa de Velázquez, 1989, pp. 213-247.

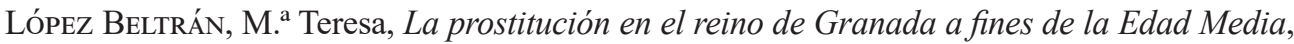
Málaga: CEDMA, 2003.

López de Coca Castañer, José Enrique, "Genoveses en la corte de los Reyes Católicos: los hermanos Italián", en Moneda y monedas en la Europa medieval (siglos XII-XV): XXVI Semana de Estudios Medievales, Estella, 19 al 23 de julio de 1999, Pamplona: Gobierno de Navarra,1999, pp. 457-484.

López de CocA, José Enrique y López Beltrán, M. a Teresa, “Mercaderes genoveses en Málaga (1487-1516). Los hermanos Centurión e Ytalián”, Historia. Instituciones. Documentos , 7 (1980), pp. 93-116.

MARÍn LóPEZ, Rafael, “Origen y evolución del patrimonio del Monasterio de San Jerónimo de Granada (siglos XVI-XVII)”, Chronica Nova, 26 (1999), pp. 215-242.

Mattingly, Garrett, "The Reputation of Doctor De Puebla”, The English Historical Review, 55 (1940), pp. 27-46.

Mattingly, Garrett, Catalina de Aragón, Madrid: Editorial Palabra, 1998.

Ortega CERA, Ágatha, "Estrategias, dinero y poder. Compañías financieras castellanas a finales de la Edad Media: una primera propuesta metodológica”, en Juan Antonio Bonachía Hernando y David Carvajal de la Vega (eds.), Los negocios del hombre. Comercio y rentas en Castilla. Siglos XV y XVI, Valladolid: Castilla Ediciones, 2012, pp. 261-286.

Padilla Mellado, Lorenzo, "El Duque de Cleves y la merced de habices que le hicieron el rey Carlos y su madre la reina Juana", Chronica Nova 37, 2011, pp. 349-378.

Penn, Thomas, Winter King: Henry VII and the Dawn of Tudor England, Londres: Simon \& Schuster, 2011. 
Petti BALBI, Giovanna, "Le strategie mercantili di una grande casata genovese: Francesco Spinola tra Bruges e Malaga (1420-1456)", Serta Antiqua et Medievalia, 1 (1997), pp. 379-393.

Prieto CANTERo, Amalia, “¿Dónde están el collar de balajes y la corona rica de la Reina Católica?”, en Estudios genealógicos, heráldicos y nobiliarios en honor de Vicente de Cadenas, Madrid, CSIC, 1978, tomo II, pp. 197-222.

Pulido Bueno, Ildefonso, La familia genovesa Centurión, (mercaderes, diplomáticos y hombres de armas), al servicio de España, 1380-1680, Huelva: Artes Gráficas Andaluzas, 2004.

"Queen Katharine: March 1509, 1-15”, en G. A. Bergenroth (ed.), Calendar of State Papers, Spain: Supplement To Volumes 1 and 2, Queen Katherine; Intended Marriage of King Henry VII To Queen Juana, Londres: Her Majesty's Stationery Office, 1868, http://www.britishhistory.ac.uk/cal-state-papers/spain/supp/vols1-2/pp13-22 [consultado el 13 de febrero de 2015].

“Queen Katharine: March 1509, 16-31”, en G. A. Bergenroth (ed.), Calendar of State Papers, Spain: Supplement To Volumes 1 and 2, Queen Katherine; Intended Marriage of King Henry VII To Queen Juana, Londres: Her Majesty's Stationery Office, 1868. http://www.britishhistory.ac.uk/cal-state-papers/spain/supp/vols1-2/pp23-34 [consultado el 15 de febrero de 2015].

“Queen Katharine: 1510”, en G. A. Bergenroth (ed.), Calendar of State Papers, Spain: Supplement To Volumes 1 and 2, Queen Katherine; Intended Marriage of King Henry VII To Queen Juana, Londres: Her Majesty's Stationery Office, 1868, publicado en: http://www.britishhistory.ac.uk/cal-state-papers/spain/supp/vols1-2/pp34-44 [última consulta: 14 enero 2015].

Rodríguez Villa, Antonio, "Un cedulario del Rey Católico (1508-1509)”, Boletín de la Real Academia de la Historia, 55 (1909), pp. 137-272.

Salazar y Castro, Luis de, Árboles de costados de gran parte de las primeras casas de estos reynos, cuyos dueños vivían en el año de 1683, Madrid: 1685.

SÁnchez Martínez, José, 'Kénosis-Diakonía' en el itinerario espiritual de San Juan de Dios, Madrid: Fundación Juan Ciudad, 1995.

SÁnchez Martínez, José, "Granada: origen del Hospital San Juan de Dios en las fuentes jerónimas (1520-1544)”, Archivo hospitalario, 4 (2006), pp. 375-398.

SÁnchez Ramos, Valeriano, "La colonia genovesa de Adra (s. XVI-XVIII)", Boletín del Instituto de Estudios Almerienses, 13 (1994), pp. 181-198.

SÁnchez-SAus, Rafael, Linajes sevillanos medievales, Sevilla: Guadalquivir, 1991.

SÁNCHEZ-SAUS, Rafael, "La aristocracia gaditana bajo el señorío de los Ponce de León (14661493)”, Estudios de historia y de arqueología medievales, 10 (1994), pp. 165-169.

SÁNCHEZ-SAus, Rafael, Linajes medievales de Jerez de la Frontera, Sevilla: Guadalquivir, 1996.

SoldANI, Maria Elisa, Uomini d'affari e mercanti toscani nella Barcellona del Quattrocento, Barcelona: CISC, 2010.

Tremlett, Giles, Catherine of Aragon: Henry's Spanish Queen, Londres: Bloomsbury, 2010.

Trillo SAn JosÉ, Carmen, La Alpujarra al final de la Edad Media, Tesis Doctoral en microfichas, Granada: Universidad de Granada, 1991.

WeIr, Alison, The Six Wives of Henry VIII, Nueva York: Grove Press, 1991 (2011).

WILKIE, William, The Cardinals Protectors of England: Rome and the Tudors before the Reformation, Londres: Cambridge University Press, 1974. 